\title{
Well Rehabilitation via the Ultrasonic Method and Evaluation of Its Effectiveness from the Pumping Test
}

\author{
Daniel Kahuda ${ }^{1,2} \mathbb{D}$, Pavel Pech ${ }^{1, * \mathbb{D}}$, Václav Ficaj ${ }^{1, *(\mathbb{D})}$ and Hana Pechová ${ }^{3}$ \\ 1 Faculty of Environmental Sciences, Czech University of Life Sciences Prague, Kamýcká 129, \\ 16500 Prague-Suchdol, Czech Republic; kahuda@fzp.czu.cz \\ 2 VODNÍ ZDROJE, a.s., Jindřicha Plachty 535/16, 15000 Praha 5, Czech Republic \\ 3 Department of Agricultural Machines, Faculty of Engineering, Czech University of Life Sciences Prague, \\ Kamýcká 129, 16500 Prague-Suchdol, Czech Republic; pechovah@tf.czu.cz \\ * Correspondence: pech@fzp.czu.cz (P.P.); ficaj@fzp.czu.cz (V.F.); Tel.: +420-724-077-070 (P.P.); \\ +420-608-369-481 (V.F.)
}

check for updates

Citation: Kahuda, D.; Pech, P.; Ficaj, V.; Pechová, H. Well Rehabilitation via the Ultrasonic Method and Evaluation of Its Effectiveness from the Pumping Test. Coatings 2021, 11, 1250. https://doi.org/10.3390/ coatings 11101250

Academic Editor: Alexandru Enesca

Received: 10 September 2021

Accepted: 12 October 2021

Published: 14 October 2021

Publisher's Note: MDPI stays neutral with regard to jurisdictional claims in published maps and institutional affiliations.

Copyright: (C) 2021 by the authors. Licensee MDPI, Basel, Switzerland. This article is an open access article distributed under the terms and conditions of the Creative Commons Attribution (CC BY) license (https:// creativecommons.org/licenses/by/ $4.0 /)$.

\begin{abstract}
The exploitation of groundwater reserves, especially for drinking purposes, is becoming increasingly important. This fact has created the need to maintain wells in the best possible functional condition. However, wells are subject to an ageing process during intensive use, which entails an increase in up-to-date resistances in the well itself and its immediate surroundings (the skin zone). This causes a decrease in the efficiency of the well (a decrease in the pumped quantity, a decrease in the specific yield, an increase of the drawdown in the well, and creation of the skin zone). The increased hydraulic gradient in the skin zone causes an increase in the inflow rate to the well, thereby inducing the movement of fine material towards the casing. This material can clog the well casing and injection ports, which is compounded by an increase in chemical and biological plugging of the skin zone. In cooperation with the company SONIC Technologies, GmbH. (Sailauf, Germany), an experimental ultrasonic technology-based well rehabilitation assembly was developed and successfully tested. This article describes the prototype development of the ultrasonic device, including its incorporation into the rehabilitation set and a demonstration of its pilot deployment in the MO-4 pumping well in Czech Republic with an evaluation of the rehabilitation effects using the authors' software (Dtest_ULTRA). Based on visual inspection and the results of hydraulic and geophysical analysis, the high efficiency of the tested technology was demonstrated in virtually all monitored parameters, where an improvement in the range of $25-55 \%$ compared to the original condition was identified.
\end{abstract}

Keywords: additional resistances; hydrodynamic well test; physical rehabilitation; ultrasound; software

\section{Introduction}

The exploitation of groundwater reserves is currently increasing. This increase also applies to the use of groundwater for drinking purposes. Moreover, the average age of water wells in Europe is steadily increasing [1,2]. During the course of their use, wells experience ageing. The main phenomena of this process are decreasing amounts of water pumped to achieve the same water level reduction in the well and increasing drawdown in the well and its immediate surroundings (the so-called skin zone) for the same amount of water pumped. The consequences of these phenomena include increases in the hydraulic gradient and flow velocity [3]. The specific yield of the well (well efficiency), which is defined as the ratio of the pumped quantity to the drawdown, subsequently decreases [4]. Well ageing is caused by various physical, chemical, and biochemical processes [5-7], such as encrustation from mineral deposits, biofouling caused by the growth of microorganisms, physical clogging of the nearby wells in which water is transmitted by sediment (well 
sanding caused by the transfer of fine materials into the well), well-screen or casing corrosion, and the formation of encrustations due to the deposition of carbonates, aluminum hydroxide deposits, and/or iron and manganese deposits (calcium carbonate, iron bacteria, silt, clay, and "slime" are all common well cloggers) [8-15].

Measures taken to correct these problems are collectively referred to as well rehabilitation (restoration or regeneration) [16]. Generally, there are two main categories of well rehabilitation: chemical and physical (mechanical). In chemical well rehabilitation, the encrusting material is dissolved using inorganic or organic acid mixtures, which are pumped into the well and left until the coatings are dissolved. The different chemical methods used for rehabilitation vary in terms of solvent composition and the way the solvent is introduced into the filter gravel [5]. Chemical rehabilitation has the major disadvantage that most such chemicals are harmful to the environment.

Physical methods include attaching a brush to a drill with high pressure jetting, hydrofracturing, and surging. In recent years, one of the technologies categorized as a physical method, the ultrasonic method, has begun to be used for well rehabilitation [17,18]. This relatively new technology was previously studied and applied to oil wells [19-25] but is also now applied to water well rehabilitation [26-29]. Hydrodynamic tests, especially pumping tests, are used to evaluate the effectiveness of well rehabilitation. Hydrodynamic tests are carried out to determine the hydraulic parameters of the groundwater aquifer (hydraulic conductivity, transmissivity, and storativity), and to determine the parameters of the pumped well itself (the coefficient of up-to-date resistances, the so-called skin factor, and well storativity). In 1935, Theis [30] published a solution for the basic equation describing the unsteady radially symmetric flow to an ideal well for a reservoir with a stressed surface based on idealized assumptions. Theis used an analogous equation for heat transfer through a solid medium to describe the groundwater flow through a porous medium. This solution is used to determine the transmissivity and storativity of the aquifer for a well with no additional resistances and a negligibly small radius. This method is known as the Theis-type curve method. Cooper and Jacob [31] simplified the Theis well function. For longer pumping test times a linear segment of drawdown vs. the logarithm of time develops during drawdown; only the first two terms are retained from the Theis well function (the error in the calculations must be less than $0.01-0.25 \%$ for the argument of the Theis function).

In real wells, pumping-test progress is significantly affected by additional resistances (expressed by the skin effect). Van Everdingen [32] and Hurst [33] were the first to introduce the additional resistances of the well and its immediate surroundings in oil-well calculations. Hawkins [34] introduced additional resistances in calculations as a zone around the well with altered hydraulic conductivity $(\mathrm{K})$. In the initial part of the pumping test, the actual well volume (called wellbore storativity) has a significant influence on the time course of the drawdown, which was first addressed in underground hydraulics by Papadopulos and Cooper [35] and then in an oil field by Ramey [36]. The basic solution of the equation for an unsteady radially symmetric fluid flow to a complete well with consideration of additional resistances and the effect of the well's own volume was published in 1970 by Agarwal et al. [37]. Subsequently, a number of authors derived various procedures and methods in this field-e.g., using type curves to determine the additional resistances and wellbore storativity from a pumping test [38-46]. The Laplace transform was one of the first techniques used to solve the basic partial differential equation of steady-state, radially symmetrical inflow to a well (see van Everdingen and Hurst [47]). The Stehfest algorithm 368 [48] was used to invert the Laplace transform in software Dtest_ULTRA.

The authors of this paper developed software using the Laplace transform and the Stehfest algorithm Dtest_ULTRA, which can be used to evaluate the "skin factor" before and after rehabilitation and from the portions of pumping tests where the line segments cannot be evaluated by the classical Cooper-Jacob method [49,50]. 


\section{Materials and Methods}

\subsection{Ultrasound}

Ultrasound refers to a mechanical wave caused by the mutual vibrations of elastic particles with frequencies higher than $20 \mathrm{kHz}$-i.e., outside the range of human hearing. Depending on the frequency, ultrasonic waves are divided into one of three categories: power ultrasound, with a frequency of $20-100 \mathrm{kHz}$; high-frequency ultrasound, with a frequency of $100 \mathrm{kHz}$ to $1 \mathrm{MHz}$; and diagnostic ultrasound, with frequencies of 1-500 MHz. The speed of wave propagation increases with greater environmental density (i.e., closer particle spacing). Thus, waves will propagate slowest in gases, faster in liquids, and fastest in solids. The source of artificially generated ultrasound is an ultrasonic generator. For low-intensity ultrasound [3], these generators include whistles, tuning forks, and sirens that are capable of generating frequencies $<200 \mathrm{kHz}$. For higher frequencies, electromechanical (piezoelectric) or magnetostrictive generators (transducers) are used. A magnetostrictive converter works on the principle of changing the dimension of the ferromagnetic material when placed in an alternating magnetic field. The propagation speed of the ultrasonic wave depends on the elasticity and density of the medium through which it passes [51]. For water, the propagation speed of ultrasonic waves is $1480 \mathrm{~m} / \mathrm{s}$.

Ultrasonic oscillations can be generated by three types of generators:

1. Mechanical (small tuning forks and whistles: low frequency and power);

2. Magnetostrictive (oscillations around an iron rod in the magnetic field of an electromagnet powered by alternating current: high power but with a frequency only up to $100 \mathrm{kHz}$ - used in dentistry and surgery);

3. Piezoelectric (a silicon wafer connected to electrodes with an alternating voltage applied that oscillates at the same frequency as the voltage, converting the energy from electrical into mechanical energy that vibrates the surrounding environmentused for diagnostic and therapeutic purposes).

High frequency will create very short-wavelength ultrasonic waves where pressure changes at the level of MPa occur at higher intensities.

1. Thermal effects: The energy of the wave is directly proportional to the square of the frequency. There is considerable absorption at the interface of tissues with different levels of acoustic impedance (soft tissue $X$ bone = periosteal pain).

2. Mechanical effects: Passage of the ultrasound wave through the environment results in local pressure changes $(\mathrm{MPa} / \mathrm{mm})$. Mechanical waves, and therefore sound, propagate in all states of matter through bonds between particles. When the energy of the oscillatory motion is transferred to adjacent particles and results in propagation of the oscillation, then the medium is characterized as elastic.

3. Physicochemical: Ultrasound has dispersive effects, which means that fine suspensions, emulsions, foams, etc. can be prepared with its power in addition to coagulative effects (e.g., used for cleaning gases).

4. Biological: $\mathrm{Up}$ to an intensity of $3 \mathrm{~W} / \mathrm{cm}^{2}$, ultrasound has biopositive effects, such as the acceleration of metabolic exchange. At intensities greater than $3 \mathrm{~W} / \mathrm{cm}^{2}$, these effects result in irreversible morphological changes, such as breakdown of the cell nucleus and the thermal coagulation of proteins.

One of the limiting factors when using ultrasonic waves for the rehabilitation of production wells is the depth of penetration of the wave through the environment, which is inversely related to the frequency of the ultrasonic wave. For casing and gravel backfill, this is, in practice, $25-35 \mathrm{~cm}$, which corresponds to the distance at which the wave amplitude drops to half its original value in a given environment. In principle, less kinetic energy is absorbed in liquids and solids than in gases. The effects of ultrasound are both mechanical and thermal. The propagation of ultrasound through a medium causes the medium's molecules to vibrate, resulting in rapid pressure changes. As ultrasound passes through organic tissues, much of the energy is converted to mechanical energy, vibrating the tissues and leading to changes in the properties of the cell membranes (physicochemical effect), 
the splitting of high molecular weight substances (chemical effect) [7], and the absorption of mechanical energy (biological effect).

In the rehabilitation of wells using ultrasonic technology, four main processes are used:

1. The removal of hard encrustations due to differences in the deformation of the grains of the gravel filter and surface precipitants. This is caused by the difference in mechanical deformation at the material interface.

2. The liquefaction of organic molecules through mechanical stress caused by ultrasound transforms of large organic molecules into smaller ones. This process yields a certain degree of lethality for viruses and bacteria.

3. Ultrasound energy leads to movements in the molecular structure of the encrustation. Consequently, abrasion occurs within the gravel, which grinds away the coating.

4. Cavitation. The so-called cavitation effect is effective up to a depth of approximately $50 \mathrm{~m}$. Cavitation removes material adhering to the gravel surface.

\subsection{Additional Resistances}

Well intervention essentially involves reducing the size of additional depressurization pores in the well and its immediate surroundings. The term "additional resistances" refers to a set of phenomena that cause a deviation in the measured values of water drawdown at the real well compared to the theoretical drawdown obtained by assuming an ideal (without additional resistances) model of water flow to the full well. The additional resistances cause most wells to lose their specific capacity with time. This is primarily due to ageing of the wells through mechanical, chemical, and biological processes. Some types of additional resistances can arise during the drilling process, leading to shortcomings and imperfections in drilling techniques and technologies, especially for the equipment used for the well itself, e.g., a reduction in permeability in the immediate vicinity of the well due to intrusion of the drilling fluid into the porous water-saturated environment during rotary drilling, resulting in so-called "water-logging." This can be caused by a "mud crust" or by impact drilling, where the porous environment in the vicinity of the well is compacted, resulting in a reduction in permeability $[12,13,39,52]$.

Other causes can include various hydromechanical, chemical, and biological phenomena that may occur in and around the well during the exploitation of the well. Knowledge of the magnitude of the additional drawdown or the additional drawdown attributable to the action of the up-to-date resistances is essential in determining the efficiency of the well and can be used to monitor the ageing process of the well.

Chemical degradation is most commonly observed in areas where the flowing water contains excessive dissolved minerals. This type of degradation is caused by the deposition of minerals on different parts of the well. The most common substances are calcium carbonate, magnesium carbonate, calcium sulphate, and manganese and iron hydroxides.

Biodegradation is caused by bacteria, which occurs naturally in most aquifers. These bacteria can be divided into three basic groups. The first and most widespread group includes iron bacteria. These bacteria cause the oxidation of iron compounds and produce ferric hydroxide, which is a red inorganic substance deposited by a biological process substance. This substance has a slimy character and is deposited on the walls of the wellbore, the individual pump sections, and the surrounding area of the well. If exposed to air, ferric hydroxide solidifies and can cause much more damage. The second group includes bacteria that reduce sulfur compounds. These bacteria can be found in extremely acidic waters-even those with a $\mathrm{pH}$ equal to 1 . The last group includes slime-producing bacteria, which coexist with the abovementioned types of bacteria. The most commonly produced slime affects parts of the pump, but slime can also clog the filter casing of the well and the pores in the aquifer surrounding the well. All of these degradation modes yield changes in the hydraulic conductivity of parts of the well and the adjacent aquifer. The sum of all these factors is called the skin effect. Parts of the additional resistance are caused, for example, by clogging (damage) of the well-i.e., blockage of the pores by 
fine material, which reduces the flow rate of the porous medium; by rock or silt particles becoming trapped in the filter holes, including chemical encrustation and blockage of the filter holes by microorganisms and bacteria; or by incomplete opening of the aquifer by the well (a so-called incomplete well). Each additional element of resistance causes an incremental increase in the water level drawdown in the well.

The total aggregate drawdown caused by the additional resistances is calculated as:

$$
\text { s_skin }=\sum_{i=1}^{n} s_{i}
$$

where $n$ is the number of partial additional resistances at the well and in its vicinity, s_skin is the drawdown caused by these additional resistances $(\mathrm{m})$, and $s_{i}$ is the drawdown caused by the -th additional resistance $(m)$.

The terms "additional drawdown" and "additional resistances" were first defined for steady flow by van Everdingen [32], who expressed the drawdown due to the total additional resistances with the following relation:

$$
\text { s_skin }=\frac{Q}{2 \pi T} S F
$$

where $Q$ is the pumping rate $\left(\mathrm{m}^{3} / \mathrm{s}\right), T$ is the transmissivity of the aquifer $\left(\mathrm{m}^{2} / \mathrm{s}\right)$, and $S F$ is the skin factor (-).

Figure 1 presents the differences in the course of the piezometric level for an ideal pumped well and a well with additional resistances.

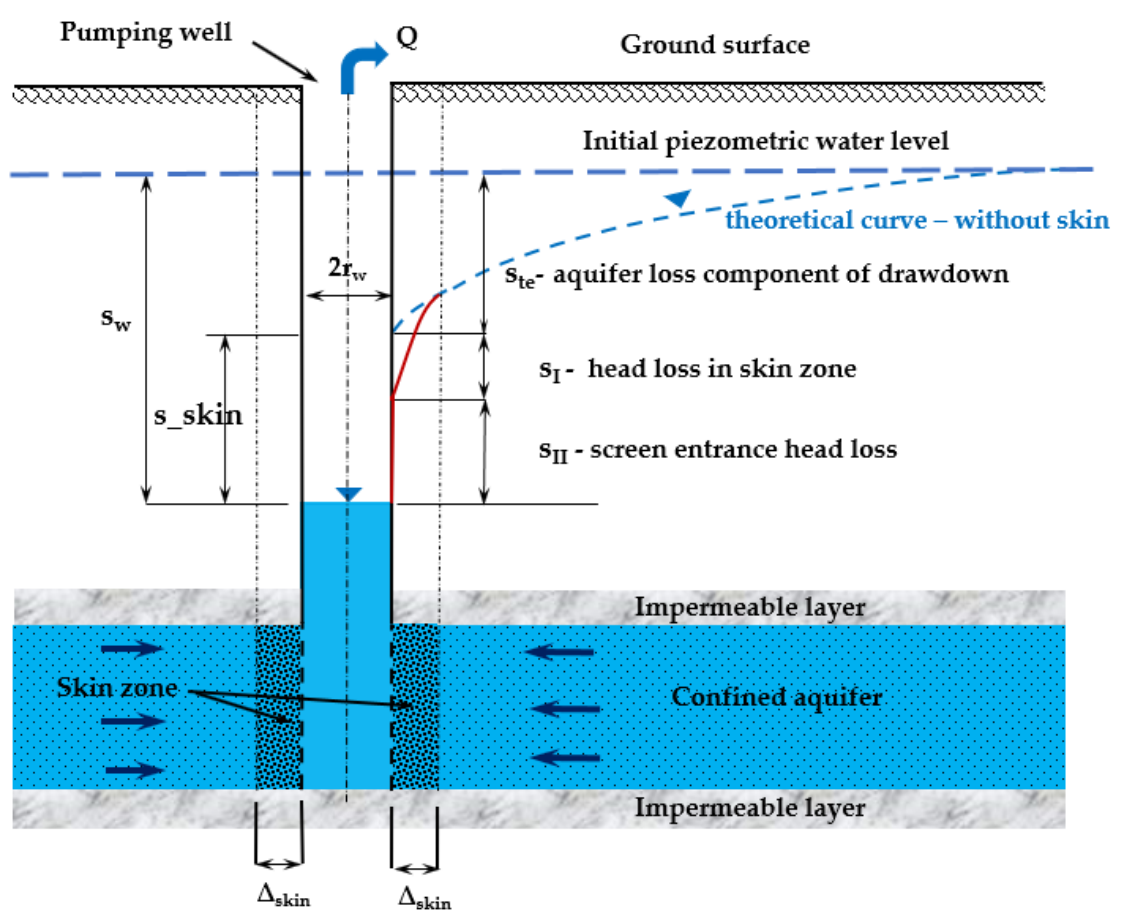

Figure 1. Well diagram with additional resistances on the well wall and in the dam aged zone.

The total drawdown in the well can be expressed as (see Figure 1)

$$
s_{w}=s_{t e}+s_{-} \text {skin. }
$$

where $s_{w}$ is the total drawdown $(\mathrm{m})$ and $s_{t e}$ is the theoretical drawdown (without additional resistances) (m). 
As a characteristic of the well condition, we use the specific yield of the well, which is the ratio of the amount of water pumped from the well to the total drawdown [53]:

$$
q=\frac{Q}{s_{w}}
$$

where $q$ is the specific yield $\left(\mathrm{m}^{2} / \mathrm{s}\right)$.

A typical plot of a pumping test, shown in semilogarithmic terms as drawdown vs. a logarithm of time, is illustrated in Figure 2, along with a section that can be evaluated by the Cooper-Jacob method.

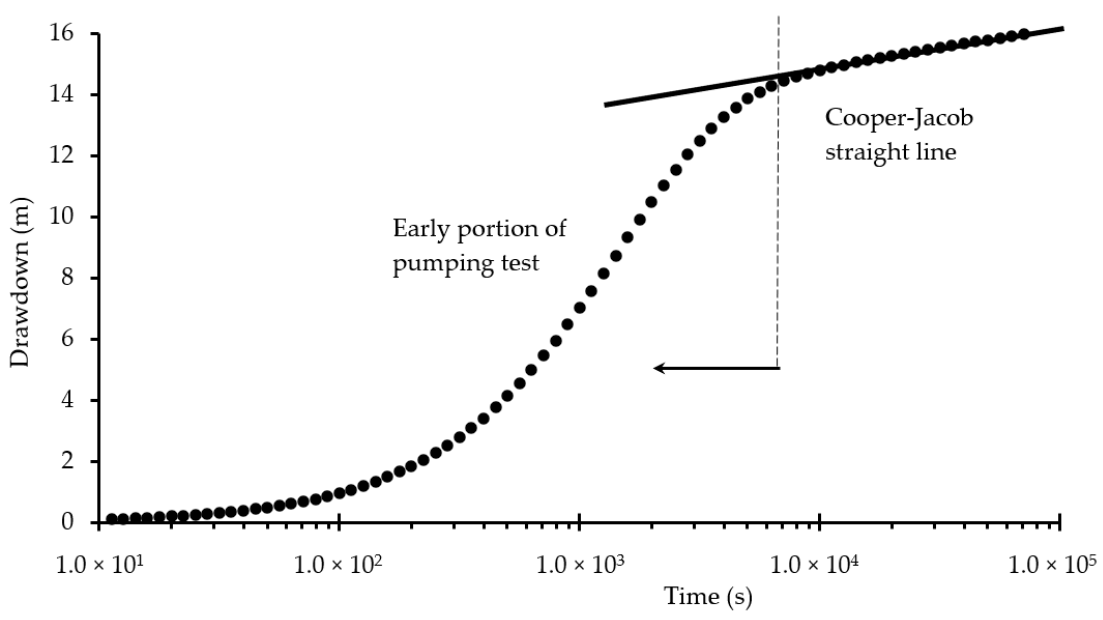

Figure 2. Diagram of a pumping test with the initial section and the Cooper-Jacob section.

For the Cooper-Jacob section (Figure 2), we can use the relation [54] of the form for groundwater to evaluate the skin factor:

$$
s \_s k i n=\frac{Q}{4 \pi T}\left(\ln \frac{2.246 T t}{r_{w}^{2} S}+2 S F\right)
$$

where $S$ is the aquifer storativity $(-), r_{w}$ is the well radius (m), and $t$ is time (s).

Next, we express the coefficient of additional resistances (skin factor):

$$
S F=\frac{2 \pi T s_{w}}{Q}-\frac{1}{2} \ln \frac{2.246 T t}{r_{w}^{2} S}
$$

In this study, if no section was evaluable by the Cooper-Jacob method, the skin factor was determined in the field example using the Dtest_ULTRA software described in [50].

The article used the following dimensionless parameters [50,55]:

- Dimensionless time

$$
t_{D}=\frac{T t}{r_{w}^{2} S}
$$

- Dimensionless radius

$$
r_{D}=\frac{r}{r_{w}}
$$

where $r=$ distance from pumped wellbore $(\mathrm{m})$.

- Dimensionless drawdown

$$
s_{D}\left(r_{D}, t_{D}\right)=\frac{2 \pi T}{Q}(s(r, t))
$$


- Dimensionless drawdown at a well

$$
s_{W D}\left(r_{D}=1, t_{D}\right)=\frac{2 \pi T}{Q}\left(s_{w}(t)\right)
$$

- $\quad$ Dimensionless wellbore storage [8]

$$
C_{D}=\frac{C}{2 \pi S r_{w}^{2}}
$$

where the $C$ is the unit factor of the wellbore storage $\left(\mathrm{m}^{2}\right), s(r, t)$ is the drawdown at distance $r$ and time $t(\mathrm{~m})$, and $s_{w}$ is the drawdown at a well $(\mathrm{m})$.

For unsteady flow in terms of dimensionless parameters, the well-known diffusivity equation in the radial coordinates has the form $[37,40,50,56-58]$

$$
\frac{\partial^{2} s_{D}}{\partial r_{D}^{2}}+\frac{1}{r_{D}} \frac{\partial s_{D}}{\partial r_{D}}=\frac{\partial s_{D}}{\partial t_{D}}
$$

Initial and boundary conditions are $[37,50]$

$$
\begin{gathered}
s_{D}\left(r_{D}, t_{D}=0\right)=0 \\
s_{w D}\left(r_{D}=1, t_{D}=0\right)=0
\end{gathered}
$$

The outer boundary condition is:

$$
s_{D}\left(r_{D}, t_{D}\right)=0
$$

The inner boundary condition if the effect of wellbore storage plays a major role and the skin factor is constant [32]

$$
\begin{gathered}
s_{w D}=s_{D}+\left(r_{D} \frac{\partial s_{D}}{\partial r_{D}}\right)_{r_{D}=1} S F \\
C_{D} \frac{\partial s_{D}}{\partial t_{D}}-\left(r_{D} \frac{\partial s_{D}}{\partial r_{D}}\right)_{r_{D}=1}=1
\end{gathered}
$$

The basic Equation (12) is solved using a Laplace transform. The following type of transform function is used to convert the partial differential equation in dimensionless parameters into an ordinary differential equation $[59,60]$ :

$$
F(p)=L(f(t))=\int_{0}^{\infty} f(t) e^{-p t} d t
$$

The transformed solution in the Laplace domain for dimensionless wellbore drawdown is:

$$
\overline{S_{w D}}=\frac{K_{0}\left(p^{1 / 2}\right)-S F p^{1 / 2} K_{1}\left(p^{1 / 2}\right)}{p\left[p^{1 / 2} K_{1}\left(p^{1 / 2}\right)+C_{D} p^{1 / 2}\left(K_{0}\left(p^{1 / 2}\right)+S F p^{1 / 2} K_{1}\left(p^{1 / 2}\right)\right)\right]}
$$

where $p$ is the Laplace operator; $K_{0}$ and $K_{1}$ are the zero and unit order modified Bessel functions, respectively; and $S F$ is the skin factor (-).

Dimensionless drawdown at a well and $s_{w d}$ was obtained by Stehfest numerical inversion [41]:

$$
s_{W D}\left(t_{D}\right)=\frac{\ln (2)}{t} \sum_{i=1}^{N} V_{i} \overline{s_{w D}}(p)
$$




$$
\begin{gathered}
p=i \frac{\ln (2)}{t} \\
V_{i}=(-1)^{\frac{n}{2}+i} \sum_{k=\left[\frac{i+1}{2}\right]}^{\min \left(i, \frac{n}{2}\right)} \frac{k^{\frac{n}{2}}(2 k !)}{\left[\left(\frac{n}{2}-k\right) ! k !(k-1) !(i-k) !(2 k-i) !\right]}
\end{gathered}
$$

$s_{W D}$ is the dimensionless wellbore drawdown in a real domain, and $\overline{s_{W D}}$ is the solution of the dimensionless well drawdown for $r_{D}$ and $t_{D}$ in Laplace space (-).

For drawdown at a well it is:

$$
\begin{gathered}
s_{w}\left(r_{w}, t\right)=\frac{Q}{2 \pi T} \sum_{j=1}^{k} \operatorname{con}(j, k) \sum_{i=0}^{m}\left(\begin{array}{c}
m \\
i
\end{array}\right)(-1)^{i} . \\
\frac{K_{0}\left(c^{1 / 2}\right)-S F c^{1 / 2} K_{1}\left(c^{1 / 2}\right)}{c\left[c^{1 / 2} K_{1}\left(c^{1 / 2}\right)+C_{D} c^{1 / 2}\left(K_{0}\left(c^{1 / 2}\right)+S F c^{1 / 2} K_{1}\left(c^{1 / 2}\right)\right)\right]}
\end{gathered}
$$

where $k=n / 2 ; m=k+1-j$; and $c=(m+i)\left(\ln (2) / t_{D}\right.$.

$$
\operatorname{con}(j, k)=\frac{(-1)^{j-1}}{k}\left(\begin{array}{c}
k \\
j
\end{array}\right) j m^{k-1} \frac{\ln 2}{t_{D}} \frac{(2 m) !}{m !(m-1) !}
$$

Equation (24) was used in the software Dtest_Ultra [50].

\section{Results}

\subsection{Development of Ultrasonic Well Recovery Equipment}

In 2017, work began on the development of an experimental ultrasonic technologybased well rehabilitation assembly. The development of the actual ultrasonic wave emitters, including their installation and wiring, were carried out by SONIC Technologies, GmbH. from Germany. Based on the requirements for the performance and applicability of the device under hydrostatic pressures up to $25 \mathrm{bar}$, the ultrasonic probe was designed based on the principle of magnetostrictive emitters, including the appropriate energy transfer and control assembly (Figure 3).
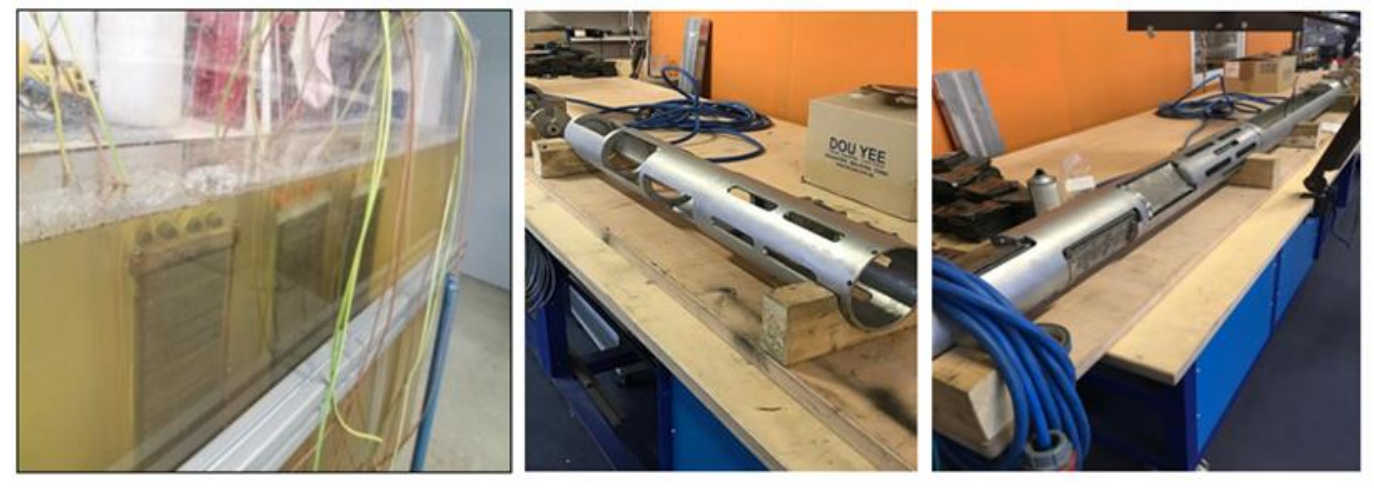

Figure 3. Laboratory testing of ultrasonic emitters (SONIC Technologies, GmbH, Sailauf, Germany).

The core of the ultrasonic device features individual switching power supplies for controlling the individual power paths of the ultrasonic emitters, which are connected by a paired cable via a low-current control. The effective frequency of the emitters is fixed at $20 \mathrm{kHz}$, and the switching frequency is optimized for an ideal power-to-performance ratio. The switching frequency was thus developed with the practical efficiency of the application in mind, and safety features were added to enable early shutdown in the event of insufficient cooling of the equipment or incorrect operation. The ultrasonic emitters are housed in a submersible probe. In addition to the specifics of the actual wave generation 
and effects, the engineering design also addressed the issues of the power supply, switching, control, cooling, and flushing within the reclaimed facility.

In 2017, the first field deployment tests of the pre-prototype were conducted (based on an older design by N. Patzner, Sonic Umwelttechnik, $\mathrm{GmbH}$ ), but due to its inconvenient operational dimensions, the prototype was only a test platform for further development. The test model demonstrated the basic functional characteristics of the method in conjunction with a submersible pump and the effectiveness of the tested principles. Shortcomings, however, were observed in the power transfer and the controls for the individual emitters. The testing was carried out in a shallow test well within the Baugrund Süd GmbH site at Bad Wurzbach, Germany. In 2018 and 2019, prototypes 1 and 2 were successively constructed and placed in a submersible probe. Development of the ultrasonic device was completed with prototype-3 in 2020 [61].

\subsection{Machine Platform}

The supporting machine platform provides the necessary manipulation, control, and resource base for operation of the probe with the ultrasonic wave emitter assembly and, at the same time, enables the integration of equipment for other rehabilitation techniques (the basic spectrum of mechanical and possibly chemical methods), which are combined in operational practice for accessing the rehabilitated surfaces of the receiving wells for input of the ultrasonic probe. The rehabilitation assembly was developed to be autonomous, i.e., as independent as possible in terms of supporting other machinery and transport equipment, as well as capable of operating in conditions without a sufficiently powerful electrical connection. The machine platform includes a standardized range of equipment and features:

- A crane with minimum lifting capacity of $2500 \mathrm{~kg}$, possible movement in two axes, and minimum lifting capacity height of $12 \mathrm{~m}$;

- An AC power generator with an effective power of $40 \mathrm{~kW}$ and $32 \mathrm{~A}$;

- A machine winch for the power cables of the ultrasonic emitters;

- A steel pipe assembly with a total length of $200 \mathrm{~m}$;

- The possibility to connect a towed compressor.

Controls and Safety Features

Specific controls and safety features were developed for the ultrasonic rehabilitation assembly and were installed on the machine platform:

- Electrical switchboard-This device allows the transfer of power energy from its own aggregate or an external source to the ultrasonic emitters and the operating pump. This switchboard is equipped with control and monitoring elements for operation of the individual emitters, controls, and pump controls, as well as integral safety elements for (a) manual and (b) automatic stopping of the cable winding in cases that exceed the safe tension force.

Frequency converter-This is the most basic part of the power winch conversion cable and allows one to control the winding speed and reverse the cable (i.e., unwinding).

- Power cable: Based on the calculated dimensions for the transmission of $15 \mathrm{~kW}$ of ultrasonic power from the emitter and submersible pump, we used a $5 \mathrm{~m} \times 6 \mathrm{~m}$ power cable with a grounding option.

Figure 4 shows the modifications of the control and safety elements. 


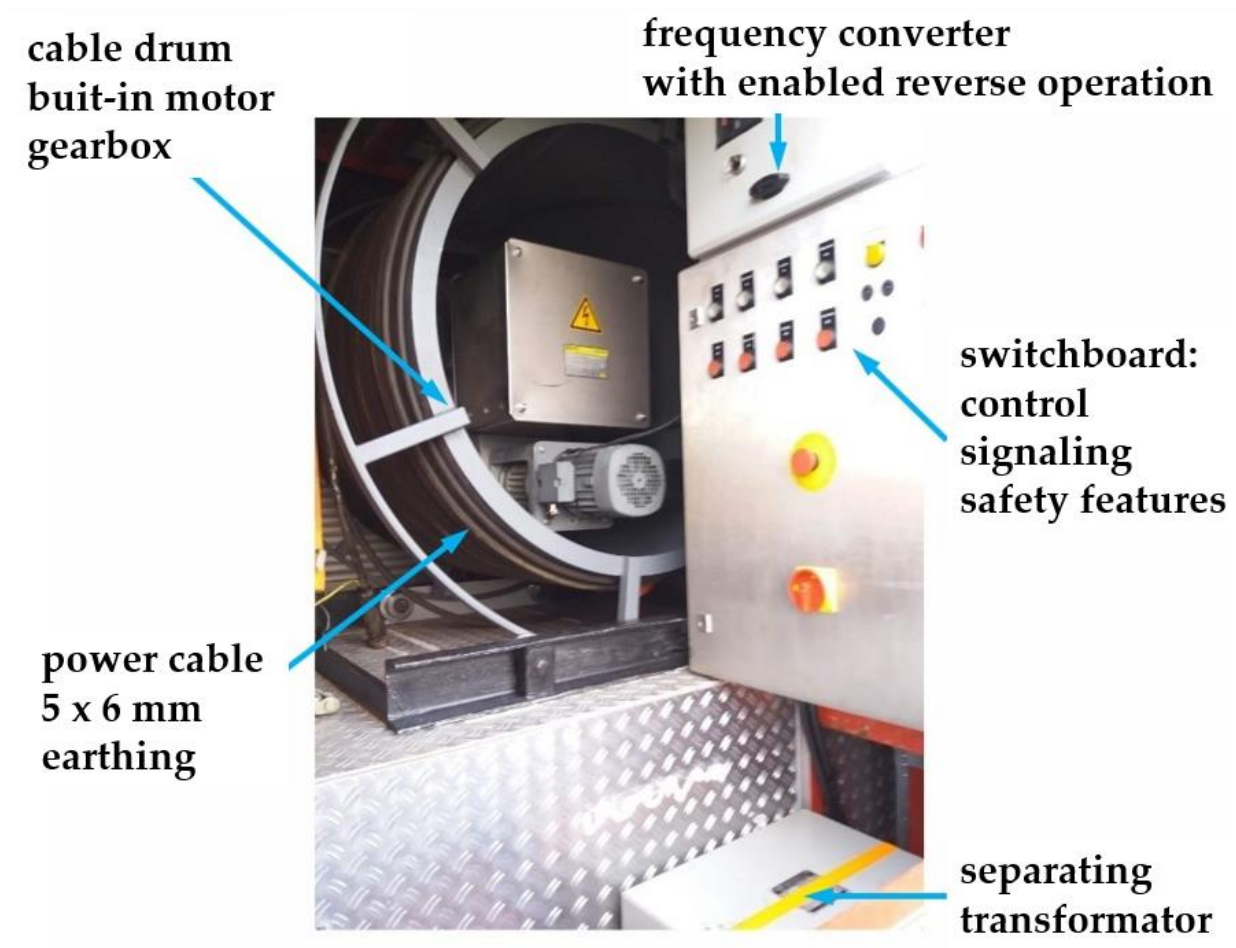

Figure 4. Operation control and safety elements.

The technical data for the system are listed in Table 1.

Table 1. Technical data for the ultrasonic set.

\begin{tabular}{lc}
\hline Technical Data for Individual Emitter & \\
\hline Operating frequency & $20 \mathrm{kHz}$ \\
Rated power & $2500 \mathrm{Watt}$ \\
Peak power & $4000 \mathrm{Watt}$ \\
Weight & approx. $18 \mathrm{~kg}$ \\
Sound emitting surface & $85 \times 185 \mathrm{~mm}$ \\
Sound energy (nominal/peak)) & $12 / 25 \mathrm{~W} / \mathrm{cm}^{2}$ \\
Modulation & double half wave \\
Ultrasonic technology & magnetostriction \\
Horizontal range & up to 350 mm from the borehole wall \\
\hline Technical Data of the Ultrasonic Device & \\
\hline Type & B $20 / 6$ \\
Number of ultrasonic emitters & 3 \\
Total power & $7.5 \mathrm{KW}$ \\
Power source & $15 \mathrm{kVA}$ \\
Main voltage & $230 / 100 / 50 \mathrm{~Hz}$ \\
Weight & $120 \mathrm{~kg}$ \\
Length & $160 \mathrm{~cm}$ \\
Weight of switching box & approx. $200 \mathrm{~kg}$ \\
Weight of cables & $2 \mathrm{~kg} / \mathrm{m}$ \\
Cable reel weight & approx. $150 \mathrm{~kg}$ \\
Outer diameter & $140 \mathrm{~mm}$ \\
External dimensions of the switch cabinet & $800 \times 1800 \times 600 \mathrm{~mm}$ \\
Applicability for bore diameter & $160-1000 \mathrm{~mm}$ \\
Maximum borehole depth & $250 \mathrm{~m}$ \\
Crane capacity & $2500 \mathrm{~kg}$ \\
Steel pipe assembly & lengths of $200 \mathrm{~m}$ \\
Alternating current generator & \\
\hline
\end{tabular}


The developed ultrasound probe ready for field application is shown in Figure 5.
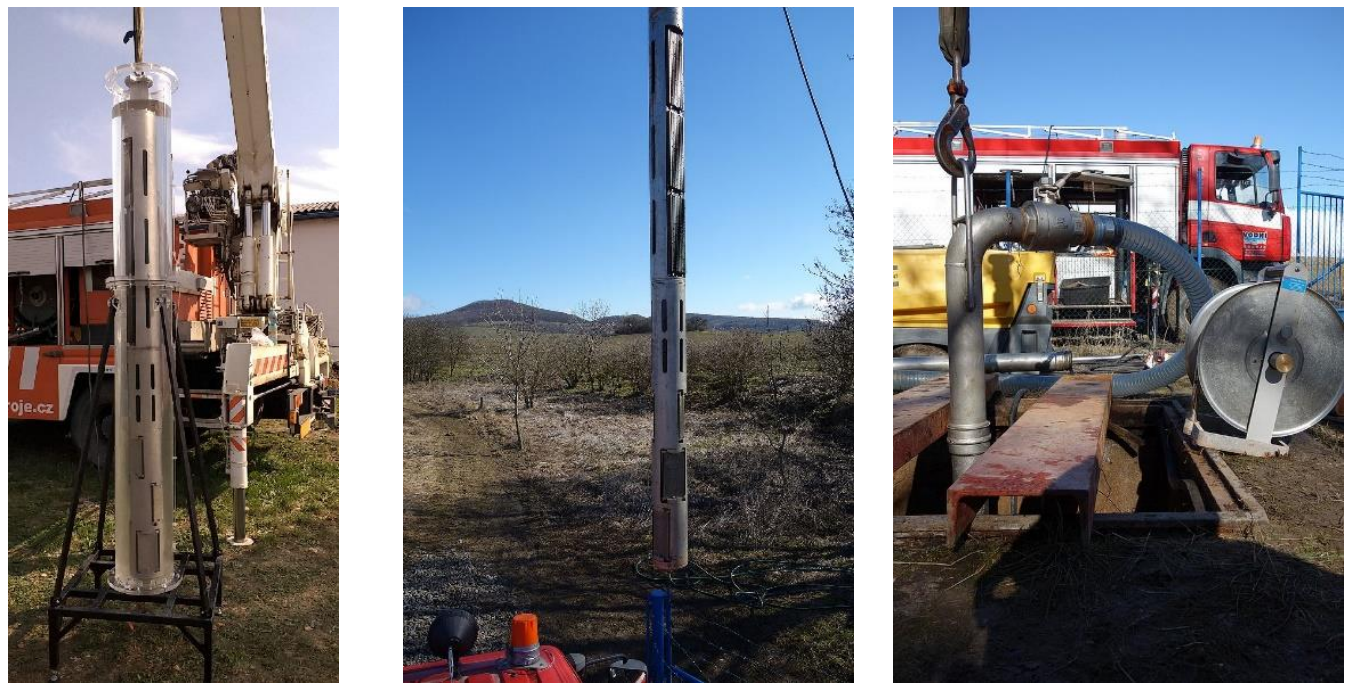

Figure 5. Ultrasonic probe in action (prototype by SONIC TECHOLOGIES, Inc.).

3.3. Field Deployment of the Ultrasonic Equipment during the MO-4 Well Rehabilitation and Evaluation of the Effects of the Rehabilitation Intervention

3.3.1. Case Study

The MO-4 well is located in North Bohemia (Czech Republic-50.50 N, 13.95 E) within the Vlastislav pumping site and operated by a major regional waterworks company (Figure 6).

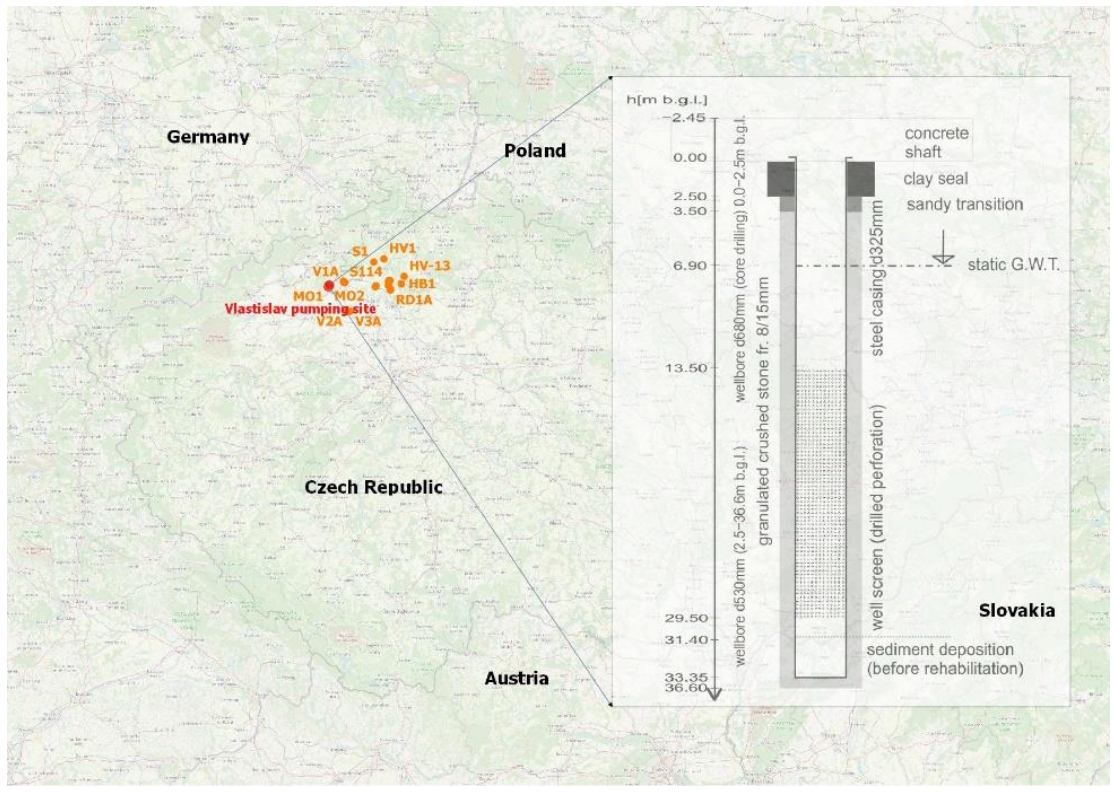

Figure 6. Location of the MO-4 well and a schematic view of the well.

The site was established in the 1960s by utilizing a spring tributary (a so-called "chapel") to a local creek called "Modla". In total, five new pumping wells were constructed to enhance the pumping capacity of the site. In 1967, the MO-4 pumping well was drilled to a final depth of $36 \mathrm{~m}$. The drilled diameter is $530 \mathrm{~mm}$, with a steel-casing diameter of $325 \mathrm{~mm}$. The well screen consists of a drilled perforation, and the filter is made of granulated stones fractionated to $8 / 15 \mathrm{~mm}$. The pumping well is screened in a phreatic aquifer, with an initial pumping capacity estimated at up to $5 \mathrm{~L} / \mathrm{s}$. 


\subsubsection{Geology and Lithology}

From a hydrogeological point of view, the well is located in the northwest corner of a regional Turonian (Late Cretaceous) aquifer with a local depth of no more than $13 \mathrm{~m}-$ see: https: / / mapy.geology.cz/geocr50/? extent $=-772846.0823 \% 2 C-995356.9083 \% 2 C-7657$ 29.1785\%2C-991236.3851\%2C102067 (accessed on 23 August 2021). This layer overlays a similarly cornered and small Cenomanian aquifer, $20 \mathrm{~m}$ in depth. The underlying Permian (Paleozoic) aquifer has only a limited hydrogeological influence (1-2 $\mathrm{m}$ thickness), and there are several fractures in the surrounding porous material with primarily local importance. The aquifer is vertically limited by an underlying bedrock layer of Proterozoic gneiss, and weathered bedrock is present at a depth of about $55 \mathrm{~m}$. The water quality meets the indicators necessary for a general water supply. Due to the depth of the Cretaceous aquifer (related to its age and lithological profile), the water hardness is moderate and characterized by significant amounts of $\mathrm{Ca}, \mathrm{Na}$, and $\mathrm{Mg}$, and elevated concentrations of $\mathrm{Fe}$. The site is located at an elevation of $313 \mathrm{~m}$ a.s.l.

\subsection{Well Rehabilitation}

The specific objective in the rehabilitation of the MO-4 Vlastislav pumping well was the deployment of the ultrasonic method in an environment where no other techniques were actually applicable (except the air lift). Due to the significant age and poor technical condition of the well, the use of other mechanical or chemical techniques threatened to irreversibly damage the facility, which still serves as a source of drinking water supply. Although in many cases the combination of ultrasonic methods with other techniques may be recommended (from an operational point of view) to synergize their effects, here the specific effect of ultrasonic well rehabilitation could instead be investigated for the MO-4 Vlastislav well. To evaluate the effects, all available methods were deployed: visual, hydrodynamic, and geophysical.

During March 2021, the MO-4 well underwent a complex mechanical rehabilitation. The initial visual inspections and geophysical well-logging measurements (carried out prior to the actual rehabilitation) highlighted the poor condition of the well casing, indicating a danger of collapse. Brush-cleaning and high-pressure water jet methods were excluded from the schedule. After the initial airlift pumping of stranded sedimentary deposits, the experimental ultrasonic method was carried out using a prototype probe constructed by SONIC TECHNOLOGIES, GmbH (Sailauf, Germany), consisting of three magnetostrictive transducers with a $20 \mathrm{kHz}$ frequency and a total output of $7.5 \mathrm{~kW}$ together with the simultaneous operation of a submersible pump. The rehabilitation equipment is shown in Figure 7.

Finally, a second air-lift pump was deployed to remove the residual sediments and those induced by ultrasound. A comparison of the conditions inside the well before and after rehabilitation at different depths is shown in Figure 8. A 3Dgeo color PAL-format immersion camera with a resolution of $750 \times 600(96 \mathrm{dpi})$ was used to capture images of the site. 


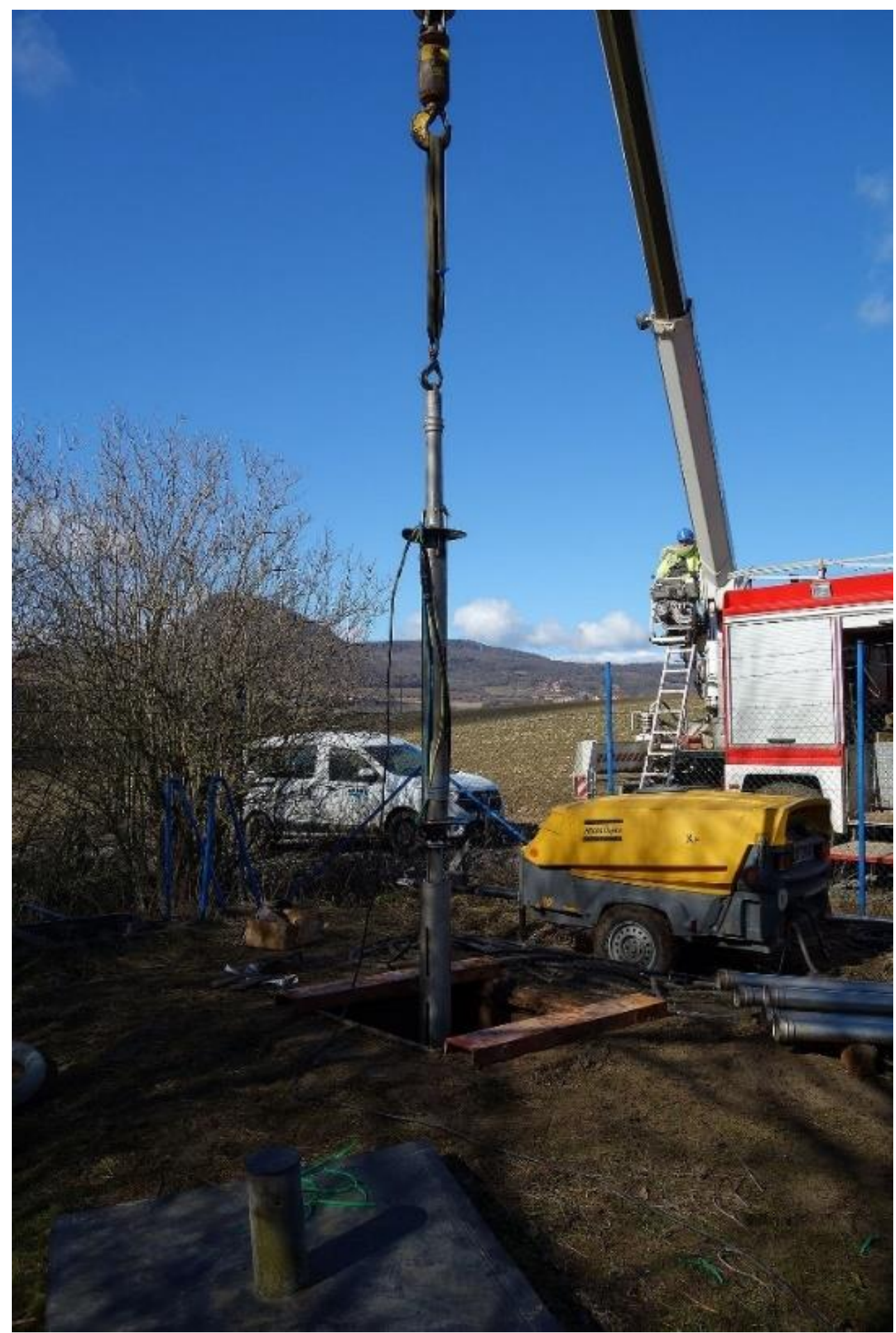

Figure 7. Rehabilitation set built within the project. 
(a)
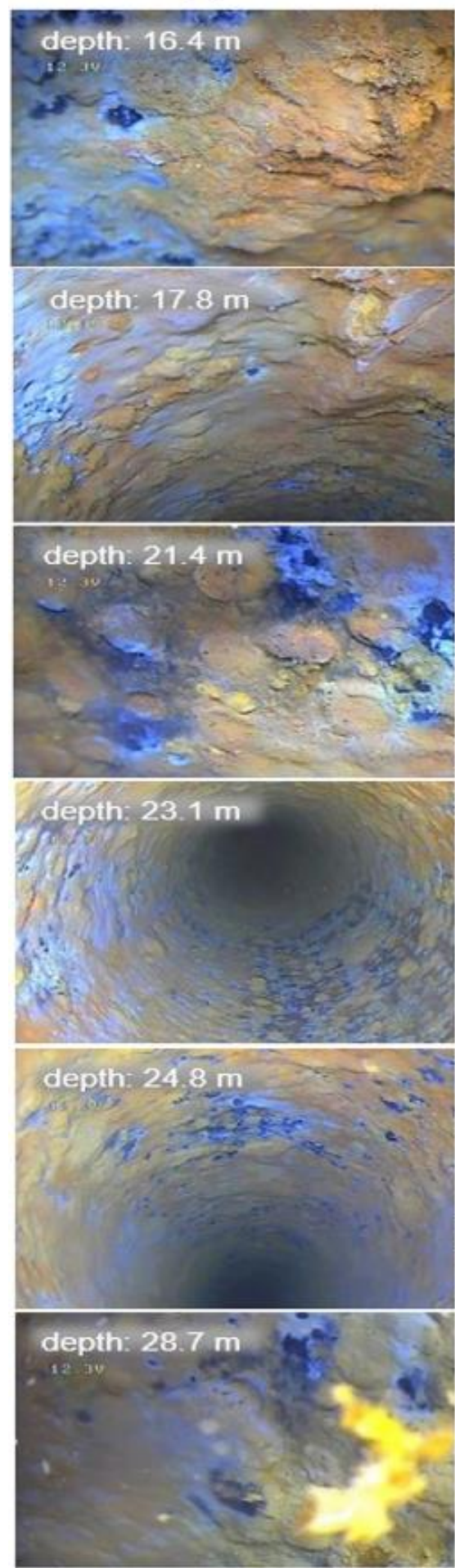

(b)
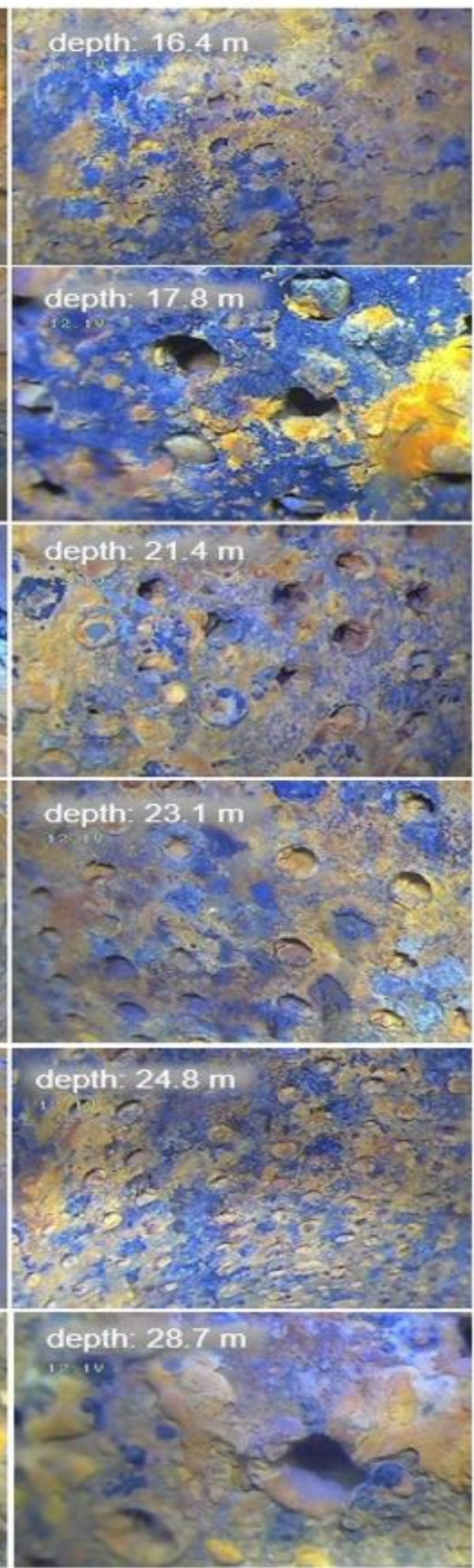

Figure 8. Example of a camera inspection of the interior of well MO-4 at different depths before (a) and after $(\mathbf{b})$ rehabilitation.

\subsection{Well Logging}

Before and after the ultrasonic rehabilitation there was a range of comparative geophysical well-logging methods applied. The measurements were performed by SG GEOTECHNIKA, a.s. (Geologická 988/4, 15200 Praha 5-Hlubočepy, Czech Republic) and the aim of the procedure was mainly to verify the current technical condition of the borehole and its functionality after the rehabilitation. The measurements intended: 
- The verification of the well technical conditions (internal, external equipment, diameters, perforations, depth);

- The verification of the internal space of the borehole by optical inspection;

- The determination of water inflows and their relative yields, and the clarification of the groundwater flow regime into the well.

\subsection{The Inspection of Well Gravel Filter}

The applied methods included:

- Gamma logging;

- Neutron neutron logging;

- Gamma gamma logging in density modification (density logging) - mainly to detect open spaces outside the well casing;

- Cavernometry - to verify the internal diameter of the well casing, possible deviations (broken casing, growths), casing joints, etc.;

- Measurement of physicochemical properties of water (conductivity, temperature, percentage of dissolved oxygen, $\mathrm{pH}$ index, oxidation-reduction potential)—to detect possible zonality of water in the borehole (from different inflows);

- Resistivimetry in the application of the labelled fluid dilution method-to clarify the groundwater and detection of inflows;

- Resistivimetry in the application of the labeled liquid pumping method—to determine all inflows and their yields.

The measured parameters were compared to the pre-rehabilitation conditions: water physical and chemical properties, water inflow, yield of permeable positions, well filter density, neutron properties of the well casing, natural gamma activity, and the borehole diameter curve (cavernometry). The results were interpreted into the following conclusions:

The removal of sediment from the well bottom increased the available depth from the original $36.0 \mathrm{~m}$ to the current $36.5 \mathrm{~m}$, which is $0.5 \mathrm{~m}$ more than the declared borehole depth. Comparison of the neutron logging curves showed a slight reduction in signal in the 11-17 m bellow terrain (b.t.) section (a greater proportion of water compared to clay suspension). In the 7.35-10.32 m b.t. section the difference was significant; however, this was influenced by a seasonal rise in groundwater level. The originally dry section is now wetted; therefore there was a significant reduction in the signal on the neutron logging curve in this section.

Regarding the changes in natural gamma activity, some reduction was observed in almost the entire borehole. This would suggest that the casing has been stripped of clay suspension.

A comparison of gamma gamma logging curves before and after rehabilitation clearly showed a density decrease in the 11-23 m section (the section with the main tributaries). This is a significant indication that the well gravel filter has been cleaned of clogging (water in the gravel filter has a lower density than the clay suspension clogging the filter pores).

Of the parameters monitored, there were virtually no changes in the $\mathrm{pH}$. Its depth course and values were almost identical before and after rehabilitation $(6.9-7.9 \mathrm{~m})$. There was an increase in the values of the oxidation-reduction potential. It now reaches positive values throughout the entire section up to the end of the well screen at $32 \mathrm{~m}$. This is probably related to the recovery of vertical flow in the well. In the section of full casing there was a sharp drop to slightly negative values. The water temperature at the bottom was similar to that before rehabilitation. However, it was slightly higher in the next section of the borehole, by up to $0.3^{\circ} \mathrm{C}$, which also can be related to the recovery of the flow. The small anomaly on the temperature curve (and on the conductivity curve) is an indicator of significant inflow. The conductivity of the water was already quite high before the rehabilitation: 1070-1200 $\mu \mathrm{S} / \mathrm{cm}$ (water with a longer residence time in the rock mass). Sulphates may have contributed to the increased mineralization in this area. Similar values occurred at the water table, whereas in another part of the well the conductivity was even higher, reaching values up to $1400 \mu \mathrm{S} / \mathrm{cm}$. This change was also related to the recovery 
of natural groundwater flow. The relative significance of the groundwater seepage was lowered, which consequently tended to lead to a lower conductivity.

Significant changes have occurred in the natural groundwater hydrodynamics in the borehole. A new significant inflow has appeared at a depth of $11.95-12.3 \mathrm{~m}$. Water now enters the borehole at a depth of 11.95-12.3 m and flows downwards. Water is added from the sandstone layer at a depth of 17.5-18.0 m (this inflow was also recorded in the first measurement before recovery). As the water continues downwards, water is added from a tributary at 20.2-21.0 m (the upper part of the coarse-grained sandstone layer below the siltstone layer with clay seal-also an inflow already detected in the first measurement). Water from all three tributaries flows through the borehole downwards with a yield of $\mathrm{Q}=7400 \mathrm{~L} /$ day. This is almost $2000 \mathrm{~L} /$ day more compared to the flow before well rehabilitation. The groundwater exits the well into a layer of silty clay at a depth of 29.2-29.7 m, with a slight residue at the end of the perforation at a depth of $32 \mathrm{~m}$.

To verify the inflows and to determine their relative yields, a marked fluid pumping method was performed in the well. The water was pumped for $1.5 \mathrm{~h}$ from a depth of $9 \mathrm{~m}$ with a constant discharge of $\mathrm{Q}=0.50 \mathrm{~L} / \mathrm{s}$. The water table dropped by $\mathrm{s}=0.51 \mathrm{~m}$ and reached a steady state. An approximate calculation showed an increase in the specific yield of approximately $20 \%$ at a pumping rate of $Q=0.5 \mathrm{~L} / \mathrm{s}$. The new inflow at a depth of 19.95-12.3 m undoubtedly contributes to the increase in the specific yield. The permeable positions, which were already evident when monitoring the natural flow using the marked fluid dilution method, were confirmed. The main inflow appeared to be from the sandstone position at a depth of $17.5-18.0 \mathrm{~m}$. This represents approximately $50 \%$ of the total yield of the well. The inflow at $20.2-21.0 \mathrm{~m}$ depth contributes approximately $15 \%$ of the total well yield and the inflow at 29.2-29.7 m depth contributes 5\%. The newly discovered inflow at $11.95-12.3 \mathrm{~m}$ depth is quite significant; it contributes $30 \%$ of the total well yield. In addition, it was shown that the natural vertical flow of water is merely an overflow between permeable positions. It is not a connection of aquifers with different discharge levels (so-called hydraulic short-circuit), and this is because if the pumping level were lowered by $0.51 \mathrm{~m}$, the direction of water movement would be reversed and water from all tributaries would start to flow towards the pump.

The new inflow of 11.95-12.3 $\mathrm{m}$ is beneficial to the well; it is located at a depth where the casing and the water properties of this inflow are not very different from those of the other inflows.

Based on a visual comparison of the results of the submersible camera inspection of the well (Figure 8) casing before and after the rehabilitation, it can be concluded that a reduction in mineral encrustations occurred throughout the entire well screen section, i.e., wherever the ultrasonic method was applied. It is estimated (from a camera inspection of the well) that approximately $70-80 \%$ of the perforation holes have been reopened, although some of the encrustation remains and therefore there is still a partial restriction of groundwater inflow to the borehole. The greatest difference was observed at 16-20 m below ground level, where (due to the location of the main groundwater inflows) the mineral encrustations reached their greatest thickness and where the geophysical well logging showed a significant inflow recovery as well as a decrease in the well filter gravel pack density. Corrosion holes were found in the profile of the borehole casing as well as the interconnection of some individual perforations.

We also compared the turbidity of the water pumped before rehabilitation and after the start of ultrasound rehabilitation (Figure 9). 


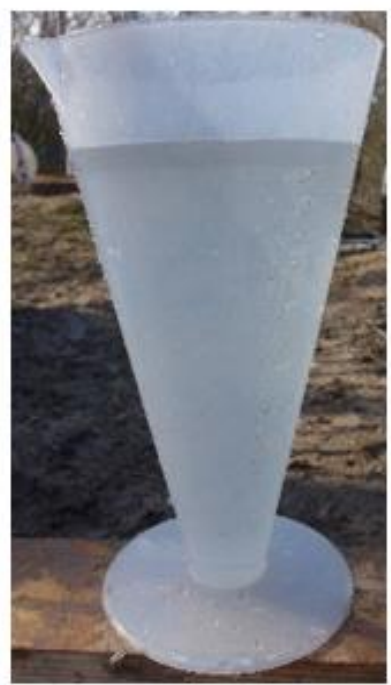

(a)

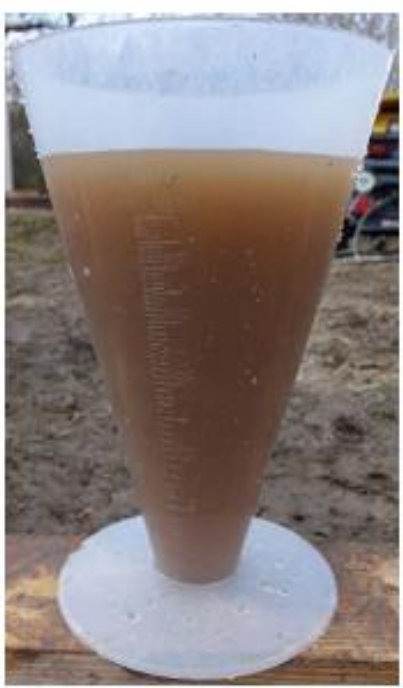

(b)

Figure 9. Comparison of turbidity in raw water before (a) and after the start (b) of ultrasound rehabilitation.

Pumping tests were performed on well MO-4 before and after rehabilitation (Table 2 and Figure 10).

Table 2. Pumping test parameters before and after rehabilitation.

\begin{tabular}{cccc}
\hline & $\begin{array}{c}Q \\
\left(\mathbf{m}^{3} / \mathbf{s}\right)\end{array}$ & $\begin{array}{c}\text { Length of Pumping Test } \\
(\mathbf{s})\end{array}$ & $\begin{array}{c}\text { max } s_{w} \\
(\mathbf{m})\end{array}$ \\
\hline Before rehabilitation & 0.0023 & 1500 & 4.2 \\
After rehabilitation & 0.0014 & 1250 & 2.05 \\
\hline
\end{tabular}

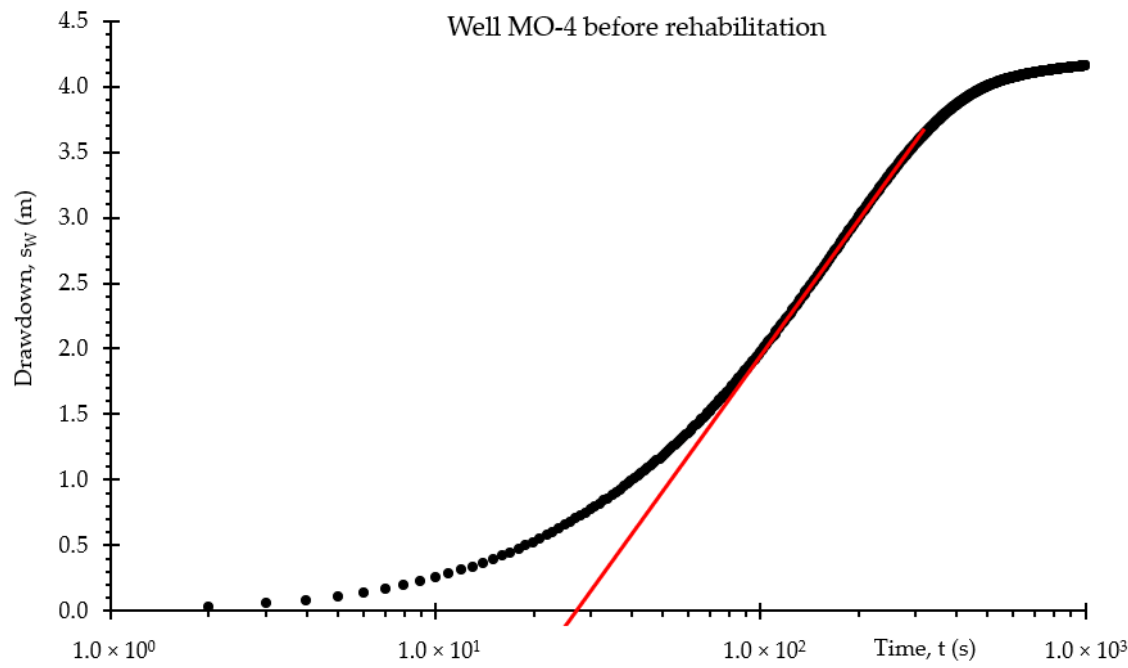

(a)

Figure 10. Cont. 


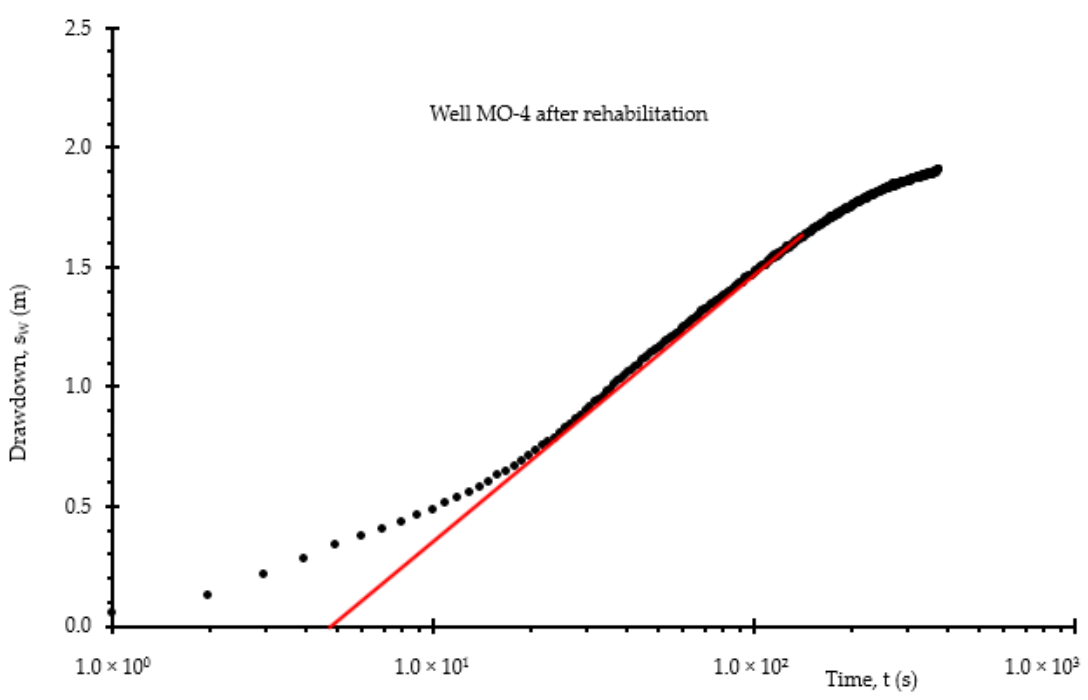

(b)

Figure 10. Well MO-4 pumping tests before (a) and after (b) rehabilitation (for the early portion of pumping test the red straight line is used in the software [50] for evaluation of the skin factor).

A semilogarithmic plot of reduction vs. a logarithm of time is shown in Figure 10.

The Dtest_ULTRA software [50] was used to determine the size of the skin effect. This software is free and subject to a GPLv3 license (the software can be downloaded from this address: https:/ /github.com/ficaj/ pumping-test (accessed on 23 August 2021). The software uses the calculation method outlined above by evaluating the skin factor from the first section of the pumping test. The software is thus able to find the equation for the line representing the first line segment (see Figure 11). In the case of unusual wells, the user can manually set the position of the straight line for the first line segment (red line) by moving a point on the slider (see Figure 11). The software is also capable of evaluating the reach of the depression cone and both the transmissivity and hydraulic conductivity of the aquifer. After the relevant calculations are completed, the user can view all results directly in the program. The project created can then be saved, so the next time the application is switched on, the user can continue working on the project. The software is able to produce a final report (see Figures 12 and 13); the user can preferentially choose which charts are ultimately included in the report. This report can be generated in either .docx or .html format.

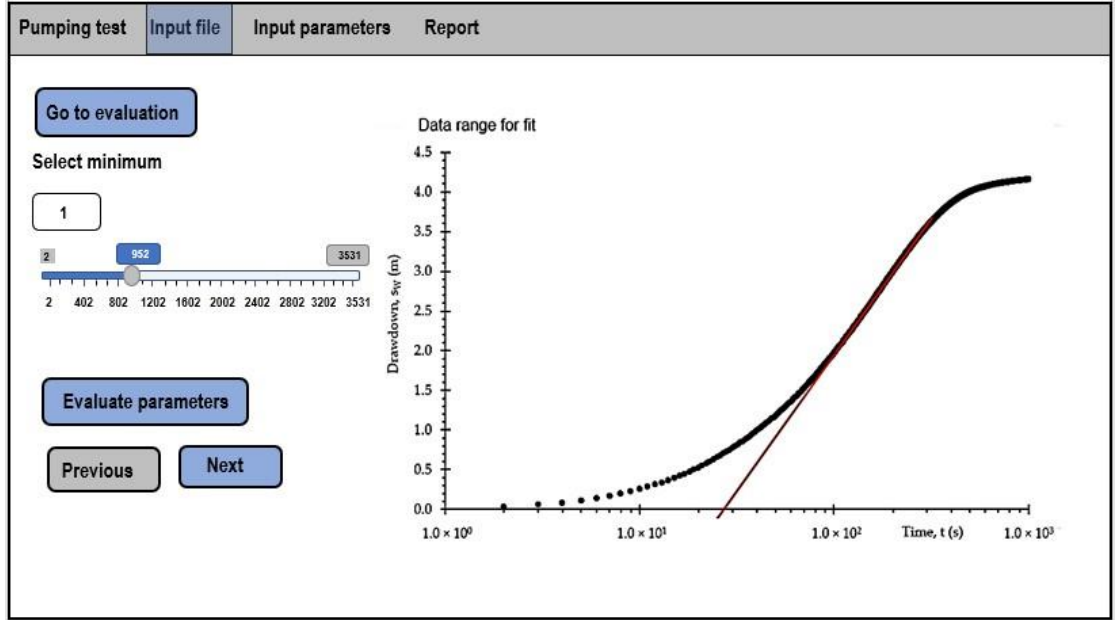

Figure 11. Dtest_ULTRA software demonstration. 


\begin{tabular}{|c|c|c|c|c|c|c|}
\hline Pumping test Input file Input parameters & \multicolumn{6}{|l|}{ Report } \\
\hline $\begin{array}{l}\text { Report options } \\
\rrbracket \text { Include }\end{array}$ & \multicolumn{6}{|c|}{ Skin effect evaluation - report } \\
\hline G Graph - input data & \multicolumn{6}{|c|}{ Evaluated on 09 July 2021} \\
\hline Graph - data used & \multicolumn{6}{|c|}{ Name of the well: MO-4 before regeneration } \\
\hline Graph - fitted values & \multirow{3}{*}{\multicolumn{6}{|c|}{$\begin{array}{l}\text { Location of the well: } \mathrm{CR} \\
\text { The pumping test was evaluated to obtain the parameters of the aquifer and additional } \\
\text { resistances. During the pumping test the pumped quantity was constant and the value was } \\
0.0023 \mathrm{~m}^{3} / \mathrm{s} \text {. The well parameters are shown in Table } 1 \text { and aquifer parameters in table } 2 \text {. }\end{array}$}} \\
\hline Select all & & & & & & \\
\hline Enter well location & & & & & & \\
\hline Vlastislav - CR & \multicolumn{3}{|c|}{ Table 1. Well parameters } & \multicolumn{3}{|c|}{ Table 2. Aquifer parameters } \\
\hline Enter well depth & \multirow{3}{*}{$\begin{array}{l}\text { Well radius } \\
\text { Wellbore } \\
\text { storage }\end{array}$} & Value & Units & & Value & Units \\
\hline 36.00 & & 0.150 & [m] & Transmissivity & 0.002560 & {$\left[\mathrm{~m}^{2} / \mathrm{s}\right]$} \\
\hline Preview report & & 1437.360 & [-] & Storativity & 0.000529 & {$[-]$} \\
\hline Output documenta format & Depth of well & 36.00 & [m] & & & \\
\hline PDF $\square$ HTML $\square$ WORD & Skin factor, SF & 16.8514 & {$[-]$} & & & \\
\hline Start new project & s_skin & 2.4096 & [m] & & & \\
\hline
\end{tabular}

Figure 12. Final report for well MO-4 before rehabilitation.

\begin{tabular}{|c|c|c|c|c|c|c|}
\hline Pumping test Input file Input parameters & \multicolumn{6}{|l|}{ Report } \\
\hline \multicolumn{7}{|l|}{ Report options } \\
\hline (1) Include & \multicolumn{6}{|c|}{ Skin effect evaluation - report } \\
\hline$\square$ Graph - input data & \multicolumn{6}{|c|}{ Evaluated on 11 July 2021} \\
\hline$\square$ Graph - data used & \multicolumn{6}{|c|}{ Name of the well: MO-4 after regeneration } \\
\hline Graph - fitted values & \multicolumn{6}{|c|}{ Location of the well: $C R$} \\
\hline & \multirow{3}{*}{\multicolumn{6}{|c|}{$\begin{array}{l}\text { The pumping test was evaluated to obtain the parameters of the aquifer and additional } \\
\text { resistances. During the pumping test the pumped quantity was constant and the value was } \\
0.0014 \mathrm{~m}^{3} / \mathrm{s} \text {. The well parameters are shown in Table } 1 \text { and aquifer parameters in table } 2 \text {. }\end{array}$}} \\
\hline Select all & & & & & & \\
\hline Enter well location & & & & & & \\
\hline CR & \multicolumn{3}{|c|}{ Table 1. Well parameters } & \multicolumn{3}{|c|}{ Table 2. Aquifer parameters } \\
\hline Enter well depth & Parameter & Value & Units & Parameter & Value & Units \\
\hline 36.00 & Well radius & 0.150 & [m] & Transmissivity & 0.002560 & {$\left[\mathrm{~m}^{2} / \mathrm{s}\right]$} \\
\hline Preview report & \multirow{2}{*}{$\begin{array}{l}\text { Wellbore } \\
\text { storage }\end{array}$} & 285.804 & {$[-]$} & \multirow[t]{2}{*}{ Storativity } & \multirow[t]{2}{*}{0.000529} & \multirow[t]{2}{*}{ [-] } \\
\hline \multirow{2}{*}{ Output documenta format } & & & & & & \\
\hline & Depth of well & 36.00 & [m] & & & \\
\hline$\oslash$ PDF $\square$ HTML $\square$ WORD & Skin factor, SF & 12.7059 & [-] & & & \\
\hline Start new project & s_skin & 1.05898 & [m] & & & \\
\hline
\end{tabular}

Figure 13. Final report for well MO-4 after rehabilitation.

\section{Discussions}

Table 3 outlines the evaluation of the field rehabilitation of demonstration well MO-4 in Vlastislav (Czech Republic) using the developed ultrasonic device. The skin factor SF was determined using the Dtest_ULTRA software [50].

Table 3 shows the success rate of the rehabilitation. The skin factor decreased by $4.15 \mathrm{~m}$, and the total drawdown after regenerative intervention was $2.15 \mathrm{~m}$ less.

The rehabilitation of well MO-4 in Vlastislav by the ultrasonic method was successful in terms of all monitored parameters. Visual inspection confirmed the removal of $2.5 \mathrm{~m}$ thickness of bottom sediments and improved opening of the perforation holes in the well screen (estimated by $70-80 \%$ ). The hydrodynamic tests showed a $24.63 \%$ reduction in skin effect, a $51.2 \%$ drawdown reduction caused by additional resistances, and a $24.18 \%$ increase in specific discharge. The geophysical well logging indicated the opening of a new 
groundwater inflow into the wellbore area and a decrease in the density of the well casing after the rehabilitation.

Table 3. Evaluation of the rehabilitation of well MO-4.

\begin{tabular}{cccccc}
\hline & $\begin{array}{c}\boldsymbol{Q} \\
\left(\mathbf{m}^{3} / \mathbf{s}\right)\end{array}$ & $\begin{array}{c}\text { Skin Factor, } S F \\
\mathbf{( - )}\end{array}$ & $\begin{array}{c}\boldsymbol{s}_{w} \\
(\mathbf{m})\end{array}$ & $\begin{array}{c}\boldsymbol{s}_{-} \text {skin } \\
(\mathbf{m})\end{array}$ & $\begin{array}{c}\text { Specific Discharge } \\
\left(\mathbf{m}^{\mathbf{2} / \mathbf{s})}\right.\end{array}$ \\
\hline Before rehabilitation (a) & 0.0023 & 16.85 & 4.2 & 2.41 & $5.5 .10^{-4}$ \\
After rehabilitation (b) & 0.0014 & 12.7 & 2.05 & 1.1 & $6.83 .10^{-4}$ \\
Difference (a), (b) & & 4.15 & 2.15 & 1.31 & $1.33 .10^{-4}$ \\
\hline Improvement by (\%) & & 24.63 & 51.2 & 54.36 & 24.18 \\
\hline
\end{tabular}

A set of borehole geophysical measurement methods was applied both before and after rehabilitation (see Figure 14). The gamma borehole geophysical method produced a decrease in the density of the casing space at depth of about 11-23 m, which can be interpreted as clearing of the collared part of the well casing behind the perforated section. The resistivimetry method also indicated a significant recovery of the inflow at 12-13 $\mathrm{m}$ [62].

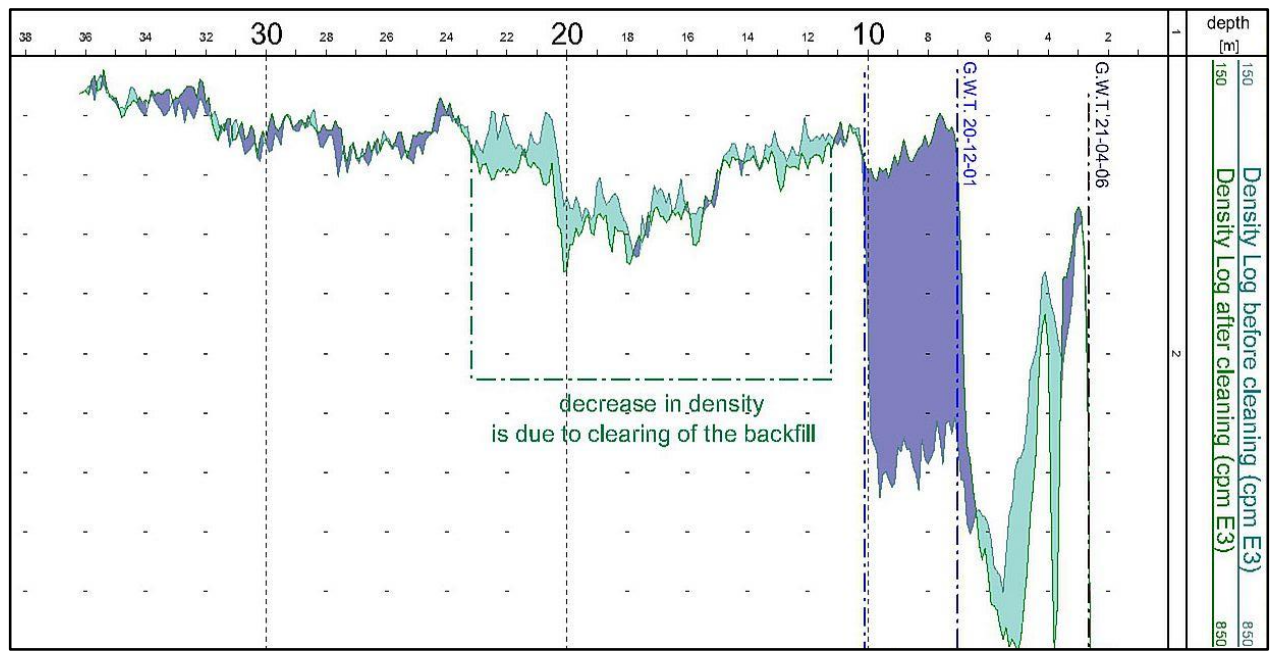

Figure 14. Well gravel pack density log before and after ultrasonic rehabilitation of well MO-4.

The application of ultrasonics in the mechanical rehabilitation of well MO-4 proved effective; however, previous experiments have indicated the necessity of simultaneous water extraction during the operation of ultrasonics. This appears to be because the effect of ultrasound is to release mineral buildup in the form of fine sediment, which is capable of reclogging the well casing area without thorough removal. For this reason, it does not seem appropriate to use the ultrasonic impact alone [63]. There is also the question of the correct sequence in the combination of rehabilitation techniques used. The basic mechanical procedures will in principle open up space for targeted application of the ultrasonic method, but the above is related to the nature of the clogging layer (in the case of well MO-4 it was primarily a hard mineral encrustation), the material, and the technical condition of the well equipment. The application of ultrasound itself leads to further deposition of sediments at the bottom of the borehole, so it seems appropriate to repeat, e.g., the air-lift pumping before and after the ultrasonic phase $[1,64,65]$. Last but not least, it is not entirely clear how far the mechanical effect of this method can be achieved, nor how long it can be effective in this way (especially in comparison with other methods) [7].

Estimated cost of MO-4 regeneration: This was an experimental well rehabilitation, but the cost can be estimated to approximately USD 5.00, excluding diagnostic work (camera inspection, pumping tests and geophysical measurements). The total cost would then be approximately USD 5800 . 
Research in this field will continue-the research team has initiated a follow-up EUREKA USOR research project.

\section{Conclusions}

Compared to other common rehabilitation techniques (Table 4), the ultrasonic method is particularly effective in reducing hard mineral encrusts and its main effect applies beyond the well casing in the area gravel filter pack, which is equally provided only by chemical methods, but at the cost of dangerous handling and the generation of toxic wastewater, which usually takes longer to remove than the rehabilitation itself. After the use of the ultrasonic method (in common with other mechanical techniques), it is possible to put the production well into operation immediately. However, the ultrasonic method cannot be used alone, but only in combination with the pumping (or air-lift) method, which is used here to remove the material released by the ultrasound impact itself. In the case of a large number of mineral or organic encrustations in the well casing or at the bottom of the well, it is advantageous to combine the ultrasonic method with one of the high-pressure methods (hydro jet...etc.), which have a more significant macroscopic effect on some types of precipitants. The decision on choice of rehabilitation techniques applied needs to be made specifically based on the available information and after an assessment of the current technical condition of the well concerned. Among the most representative results of the experimental well rehabilitation by means of ultrasound are the reduction of additional resistances and the increase of specific yield, which are accompanied by a demonstrable reduction of density in the filter area of the well.

Table 4. Advantages and disadvantages of "ULTRA" solution in comparison to other solutions.

\begin{tabular}{|c|c|c|c|c|c|c|}
\hline \multicolumn{6}{|c|}{ Impact } & \multirow{2}{*}{$\begin{array}{c}\text { Operation } \\
\text { CONs }\end{array}$} \\
\hline $\begin{array}{l}\text { Physical } \\
\text { Methods }\end{array}$ & $\begin{array}{l}\text { Bottom } \\
\text { Sediment }\end{array}$ & $\begin{array}{c}\text { Well } \\
\text { Casing }\end{array}$ & $\begin{array}{l}\text { Well } \\
\text { Filter }\end{array}$ & $\begin{array}{c}\text { Toxic } \\
\text { Wastewater }\end{array}$ & PROs & \\
\hline $\begin{array}{c}\text { Air-lift } \\
\text { pumping methods }\end{array}$ & $\begin{array}{l}\text { YES } \\
\text { limited }\end{array}$ & $\begin{array}{l}\text { limited } \\
\text { NO }\end{array}$ & $\begin{array}{c}\mathrm{NO} \\
\text { limited }\end{array}$ & $\begin{array}{l}\mathrm{NO} \\
\mathrm{NO}\end{array}$ & $\begin{array}{l}\text { easy } \\
\text { easy }\end{array}$ & $\begin{array}{l}\text { limited dept range } \\
\text { low effectivity }\end{array}$ \\
\hline Brushes & $\mathrm{NO}$ & limited & $\mathrm{NO}$ & $\mathrm{NO}$ & easy & $\begin{array}{c}\text { low effectivity, may cause } \\
\text { damages }\end{array}$ \\
\hline Water jet & $\mathrm{NO}$ & YES & limited & $\mathrm{NO}$ & $\begin{array}{l}\text { effective, thin } \\
\text { profile }\end{array}$ & $\begin{array}{c}\text { expensive, may cause } \\
\text { damages }\end{array}$ \\
\hline $\begin{array}{c}\text { Air jet } \\
\text { (hydropulse) }\end{array}$ & $\mathrm{NO}$ & YES & limited & $\mathrm{NO}$ & $\begin{array}{l}\text { effective, thin } \\
\text { profile } \\
\text { effective, }\end{array}$ & $\begin{array}{l}\text { complex, expensive, may } \\
\text { cause damages }\end{array}$ \\
\hline Ultrasound & $\mathrm{NO}$ & YES & YES & $\mathrm{NO}$ & $\begin{array}{l}\text { material- } \\
\text { friendly }\end{array}$ & complex, expensive \\
\hline \multicolumn{7}{|l|}{ Chemical methods } \\
\hline $\begin{array}{l}\text { Acidic } \\
\text { solvents }\end{array}$ & YES & YES & YES & YES & effective, cheap & $\begin{array}{c}\text { dangerous, } \\
\text { creates toxic wastewater }\end{array}$ \\
\hline Oxidants & limited & YES & limited & YES & cheap & $\begin{array}{c}\text { dangerous, } \\
\text { creates toxic wastewater }\end{array}$ \\
\hline
\end{tabular}

Similar effects achieved at three other wells in the Czech Republic using a trial deployment of ultrasound regeneration can be found at home.czu.cz/pech (accessed on 23 August 2021) (in Czech).

The ultrasonic method is a suitable addition to the spectrum of ways to rehabilitate wells, not only for extraction wells but also for injection wells. Ultrasonic well rehabilitation has a number of advantages over other methods. However, its effectiveness lies mainly in its ability to degrade clogging growths of inorganic and organic origin within the space behind the casing and outside the well casing. This method neither requires the 
application of chemical substances nor causes any intrinsic chemical reactions, which not only makes this technique environmentally friendly but also shortens the preparation time needed for the rehabilitation work (compared to chemical methods); furthermore, ultrasonication can be applied without the need for approval from the water authorities or other state administration bodies. The ultrasonic method is also non-destructive to the structural materials of the intake structures. Moreover, it was previously shown [21,39] that ultrasound does not have a negative effect on the well equipment, regardless of the material used (e.g., PVC, PE, ceramic, wood, steel, copper, resin-bonded gravel screens, or coiled wire). This method does not put any strain on the well equipment, the casing, or the surroundings, thereby prolonging the operational lifetime of the containment objects. The effect of ultrasound is immediate and effective and can significantly reduce the time required for carrying out recovery efforts.

Ultimately, within the framework of the TAČR project TH02030421 ULTRA, a fully functional ultrasonic device for the rehabilitation of pump and seepage wells was developed. This rehabilitation rig is self-contained, independent of support from other machinery and transport equipment, and can be operated even without an available electrical connection.

Author Contributions: Conceptualization, D.K. and P.P.; methodology, D.K.; software, V.F.; validation, D.K. and V.F.; investigation, P.P.; resources, D.K.; writing-original draft preparation, V.F., D.K. and P.P.; writing-review and editing, P.P., V.F., D.K. and H.P.; project administration, P.P. All authors have read and agreed to the published version of the manuscript.

Funding: This research was funded by the Technology Agency of the Czech Republic (grant number TH02030421) under the project titled ULTRA—Technology for Pumping Well Rehabilitation Based on Ultrasound Emission.

Institutional Review Board Statement: Not applicable.

Informed Consent Statement: Not applicable.

Data Availability Statement: Data supporting the reported results can be found at https: / / github. com/Ficaj/Wtest (accessed on 12 August) (software) and home.czu.cz/pech (accessed on 23 August 2021) (reports).

Conflicts of Interest: The authors declare no conflict of interest.

\section{References}

1. Abramova, A.V.; Abramov, V.O.; Bayazitov, V.M.; Nikonov, R.V. A method for water well regeneration based on shock waves and ultrasound. Ultrason. Sonochem. 2017, 36, 375-385. [CrossRef]

2. Houben, G.J.; Weihe, U. Spatial Distribution of Incrustations around a Water Well after 38 Years of Use. Ground Water 2010, 48, 53-58. [CrossRef] [PubMed]

3. Mason, T.J.; Collings, A.; Sumel, A. Sonic and ultrasonic removal of chemical contaminants from soil in the laboratory and on a large scale. Ultrason. Sonochem. 2004, 11, 205-211. [CrossRef] [PubMed]

4. Izadifar, Z.; Babyn, P.; Chapman, D. Mechanical and Biological Effects of Ultrasound: A Review of Present Knowledge. Ultrasound Med. Biol. 2017, 43, 1085-1104. [CrossRef] [PubMed]

5. van Beek, C.G.E.M.; Breedveld, R.J.M.; Juhász-Holterman, M.; Oosterhof, A.; Stuyfzand, P.J. Cause and prevention of well bore clogging by particles. Hydrogeol. J. 2009, 17, 1877-1886. [CrossRef]

6. Mullakaev, M.S.; Abramov, V.O.; Abramova, A.V. Development of ultrasonic equipment and technology for well stimulation and enhanced oil recovery. J. Pet. Sci. Eng. 2015, 125, 201-208. [CrossRef]

7. Houben, G.; Treskatis, C. Water Well Rehabilitation and Reconstruction, 3rd ed.; McGraw Hill Professional: Two Penn Plaza, NY, USA, 2007; ISBN 0-07-148651-8.

8. Available online: https://www.sonic-technologies.com/pdf/results_of_ultrasonic-well-rehabilitation.pdf (accessed on 6 July 2021).

9. Mullakaev, M.S.; Abramov, V.O.; Abramova, A.V. Ultrasonic automated oil well complex and technology for enhancing marginal well productivity and heavy oil well recovery. J. Pet. Sci. Eng. 2017, 159, 1-7. [CrossRef]

10. Timmer, H.; Verdel, J.; Jongmans, A.G. Well clogging by particles in Dutch well fields. J. Am. Water Work. Assoc. 2003, 95, 112-118. [CrossRef]

11. Houben, G.J. Iron oxide incrustations inWells_Part 1: Genesis, mineralogy and geochemistry. Appl. Geochem. 2003, 18, 927-939. [CrossRef] 
12. Adebayo, A.R.; Bageri, B.S. A simple NMR methodology for evaluating filter cake properties and drilling fluid-induced formation damage. J. Pet. Explor. Prod. Technol. 2019, 9, 1643-1655. [CrossRef]

13. Bageri, B.S.; Al-Mutairi, S.H.; Mahmoud, M.A. Different techniques for characterizing the filter cake. Soc. Pet. Eng. 2013, 1. [CrossRef]

14. Iscan, A.G.; Kok, M.V.; Bagci, A.S. Permeability Reduction Due to Formation Damage by Drilling Fluids. Energy Sources 2007, 29, 851-859. [CrossRef]

15. Ralph, D.E.; Stevenson, J.M. The role of bacteria in well clogging. Water Res. 1995, 29, 365-369. [CrossRef]

16. Houben, G.J. Review: Hydraulics of water wells-head losses of individual components. Hydrogeol. J. 2015, 23, 1659-1675. [CrossRef]

17. Zhu, P.; Song, Z.; Wu, X.; Xu, P.; Zhang, X.; Zhu, W. Community Distribution of Biofilms along a Vertical Wellbore in a Deep Injection Well during Petroleum Production. Energy Fuels 2021, 35, 1998-2005. [CrossRef]

18. Payne, F.; Quinnan, J.; Potter, S. Remediation Hydraulics; CRC Press: London, UK, 2008; p. 432. ISBN 978-0849372490.

19. Feng, F.; Mal, A.; Kabo, M.; Wang, J.C.; Bar-Cohen, Y. The mechanical and thermal effects of focused ultrasound in a model biological material. J. Acoust. Soc. Am. 2005, 117, 2347-2355. [CrossRef]

20. Mullakaev, M.S.; Abramov, V.O.; Abramova, A.V. Ultrasonic piezoceramic module and technology for stimulating lowproductivity wells. J. Pet. Sci. Eng. 2017, 158, 529-534. [CrossRef]

21. Abramov, V.O.; Mullakaev, M.S.; Abramova, A.V.; Esipov, I.B.; Mason, T.J. Ultrasonic technology for enhanced oil recovery from failing oil wells and the equipment for its implemention. Ultrason. Sonochem. 2013, 20, 1289-1295. [CrossRef]

22. Abramov, V.O.; Abramova, A.V.; Bayazitov, V.M.; Marnosov, A.V.; Kuleshov, S.P.; Gerasin, A.S. Selective ultrasonic treatment of perforation zones in horizontal oil wells for water cut reduction. Appl. Acoust. 2016, 103, 214-220. [CrossRef]

23. Mullakaev, M.S.; Abramov, O.V.; Abramov, V.O.; Gradov, O.; Pechkov, A.A. An ultrasonic technology for productivity restoration in low-flow boreholes. Chem. Pet. Eng. 2009, 45, 203-210. [CrossRef]

24. Abramov, V.O.; Abramova, A.V.; Bayazitov, V.M.; Altunina, L.K.; Gerasin, A.; Pashin, D.S.; Mason, T.J. Sonochemical approaches to enhanced oil recovery. Ultrason. Sonochem. 2015, 25, 76-81. [CrossRef]

25. Mohsin, M.; Meribout, M. An extended model for ultrasonic-based enhanced oil recovery with experimental validation. Ultrason. Sonochem. 2015, 23, 413-423. [CrossRef] [PubMed]

26. Hamida, T.; Babadagli, T. Analysis of capillary interaction and oil recovery under ultrasonic waves. Transp. Porous Media 2007, 70, 231-255. [CrossRef]

27. Petrauskas, A. Increasing the efficiency of water well regeneration with ultrasound by using acoustic transducers consisting ofelements in flexural vibrations. Ultragarsas/Ultrasound 2009, 64, 17-23.

28. Daghooghi-Mobarakeh, H.; Campbell, N.; Bertrand, W.K.; Kumar, P.G.; Tiwari, S.; Wang, L.; Wang, R.; Miner, M.; Phelan, P.E. Ultrasound-assisted regeneration of zeolite/water adsorption pair. Ultrason. Sonochem. 2020, 64, 105042. [CrossRef]

29. Aarts, A.C.T.; Gijs, O.; Bil, K.J.; Bot, E.T.G. Enhancement of Liquid Flow Through a Porous Medium by Ultrasonic Radiation. SPE J. 1999, 4, 321-327. [CrossRef]

30. Theis, C.V. The relation between the lowering of the piezometric surface and the rate and duration of discharge of a well using ground-water storage. Trans. Am. Geophys. Union 1935, 16, 519-524. [CrossRef]

31. Cooper, H.H.; Jacob, C.E. A generalized graphical method for evaluating formation constants and summarizing well-field history. Trans. Am. Geophys. Union 1946, 27, 526-534. [CrossRef]

32. Van Everdingen, A.F. The skin effect and its influence on the productive capacity of a well. J. Pet. Technol. 1953, 5, 171-176. [CrossRef]

33. Hurst, W. Establishment of skin effect and its impediment to fluid flow into a well bore. Pet. Eng. 1953, 25, B6-B16.

34. Hawkins, M.F., Jr. A note on the skin effect. Trans. Am. Inst. Min. Metall. Eng. 1956, 8, 356-357. [CrossRef]

35. Papadopulos, I.S.; Cooper, H.H. Drawdown in a well of large diameter. Water Resour. Res. 1967, 3, 241-244. [CrossRef]

36. Ramey, H.H., Jr. Short-time well test data interpretation in the presence of skin effect and wellbore storage. J. Pet. Technol. 1970, 22, 97-104. [CrossRef]

37. Agarwal, R.G.; Al-Hussainy, R.; Ramey, H.J. An investigation of well storage and skin effect in unsteady liquid flow: I. Analytical treatment. Soc. Pet. Eng. J. 1970, 10, 279-291. [CrossRef]

38. Fan, Z.; Rarashar, R. Transient flow to a finite-radius well with well storage and skin effect in a poroelastic confined aquifer. Adv. Water Resour. 2020, 142, 103604. [CrossRef]

39. Patel, M.C.; Singh, A. Near Wellbore Damage and Types of Skin Depending on Mechanism of Damage. In Proceedings of the Society of Petroleum Engineers SPE International Conference and Exhibition on Formation Damage Control, Lafayette, LA, USA, 24-26 February 2016.

40. Liu, S. Load characteristics of high power sandwich piezoelectric ultrasonic transducers. Ultrasonics 2005, 43, 365-373. [CrossRef]

41. Watlton, W.C. Aquifer Test Modeling, 1st ed.; CRC Press: Boca Ralton, FL, USA, 2007; p. 240. ISBN 978-1-4200-4292-4.

42. Batu, V. Aquifer Hydraulics: A Comprehensive Guide to Hydrogeologic Data Analysis; John Wiley \& Sons: New York, NY, USA, 1998.

43. Kresic, N. Hydrogeology and Groundwater Modeling, 2nd ed.; CRC Press, Taylor and Francis: Boca Raton, FL, USA, 2007; ISBN 978-0849333484.

44. Bourdet, D.; Whittle, T.M.; Douglas, A.A.; Pirard, Y.M. A new set of type curves simplifies well test analysis. World Oil 1983, 196, 95-106. [CrossRef] 
45. Novakowski, K.S. A Composite analytical model for analysis of pumping tests affected by weell bore storage and finite thickness skin. Water Resour. Res. 1989, 25, 1937-1946. [CrossRef]

46. Yeh, H.D.; Yang, S.Y.; Peng, H.Y. A new closed-form solution for a radial two-layer drawdown equation for groundwater under constant-flux pumping in a finite-radius well. Adv. Water Resour. 2003, 26, 747-757. [CrossRef]

47. Van Everdingen, A.F.; Hurst, W. The application of the Laplace transformation to flow problems in reservoirs. J. Pet. Technol. 1949, 1, 305-324. [CrossRef]

48. Stehfest, H. Algorithm 368: Numerical inversion of Laplace transforms. Commun. ACM 1970, 13, 47-49. [CrossRef]

49. Holub, J.; Pech, P.; Kuraz, M.; Maca, P.; Kahuda, D. Evaluation of a pumping test with skin effect and well storage on a confined aquifer in the Bela Crkva, Serbia. Int. J. Water 2019, 13, 1-11. [CrossRef]

50. Ficaj, V.; Pech, P.; Kahuda, D. Software for Evaluating Pumping Tests on Real Wells. Appl. Sci. 2021, 11, 3182. [CrossRef]

51. Jüttnerová, S.; Bryjová, J. Interactive Textbook of Ultrasonography. VŠB-TU, Ostrava. 2016. Available online: http://www. jtarchitekt.cz/pdf/ultrasonografie.pdf (accessed on 8 July 2021). (In Czech).

52. Zhang, Z.; Guo, J.; Liang, H.; Liu, Y. Numerical simulation of skin factors for perforated wells with crushed zone and drilling-fluid damage in tight gas reservoirs. J. Nat. Gas Sci. Eng. 2021, 90, 103907. [CrossRef]

53. Sterrett, J.R. Groundwater and Wells, 3rd ed.; Johnson screens-Weatherford comp.: New Brighton, MN, USA, 2007; p. 812. ISBN 978-0-9787793-0-6.

54. Horne, R.N. Modern Well Test Analysis: A Computer Aided Approach, 4th ed.; Alto, P., Ed.; Petroway, Inc.: Palo Alto, CA, USA, 1995; p. 185. ISBN 0-9626992-09.55.

55. Kahuda, D.; Pech, P. A new method for evaluation of well rehabilitation from the early-portion of the pumping test. Water 2020, 12, 744. [CrossRef]

56. Park, E.; Zhan, H.B. Hydraulics of a finite-diameter horizontal well with wellbore storage and skin effect. Adv. Water Resour. 2002, 25, 389-400. [CrossRef]

57. Chen, C.S.; Chang, C.C. Theoretical evaluation of non-uniform skin effect on aquifer response under constant rate pumping. J. Hydrol. 2006, 317, 190-201. [CrossRef]

58. Pasandi, M.; Samani, N.; Barry, D.A. Effect of well and finite thickness skin on flow to a partially penetrating well in a phreatic aquifer. Adv. Water Resour. 2008, 31, 383-398. [CrossRef]

59. Yeh, H.D.; Wang, C.T. A semianalytical solution for residual drawdown at a finite diameter well in a confined aquifer. J. Am. Water Resour. Assoc. 2013, 49, 966-972. [CrossRef]

60. Sethi, R. A dual-well step drawdown method for the estimation of linear and non-linear flow parameters and well skin factor in confined aquifer systems. J. Hydrol. 2011, 400, 187-194. [CrossRef]

61. Well Rehabilitation with High-Energetic Ultrasound. Sonic Umwelttecchnik. SONIC Information No. E1-09.2009. Available online: www.sonic-umwelttechnik.de (accessed on 8 July 2021).

62. Procházka, M. VLASTISLAV U TǨEBENIC, Zpráva o Revizním Karotážním Měření ve Vodárenském vrtu po Provedené Regeneraci, SG Geotechnika, a.s., Praha 2021. Available online: Home.czu.cz/pech (accessed on 5 July 2021). (In Czech).

63. Zhang, G.J.; Wang, S.F.; Liu, Z.Z. Ultrasonic regeneration of granular activated carbon. Environ. Eng. Sci. 2003, 20, 57-64. [CrossRef]

64. Gungor-Demirci, G.; Lee, J.; Keck, J.; Harrison, S.J.; Bates, G. Development of a risk-based tool for groundwater well rehabilitation and replacement decisions. J. Water Supply Res. Technol. AQUA 2019, 68, 411-419. [CrossRef]

65. Mansuy, N. Water Well Rehabilitation; CRC Press: Boca Raton, FL, USA, 2017; pp. 113-149. [CrossRef] 